\title{
ACERVO ARQUEOLÓGICO DO FORTE ORANGE - ESTRUTURAS PRESERVADAS
}

\author{
Marcos Antonio Gomes de Mattos \\ de Albuquerque*
}

Veleda Christina Lucena de Albuquerque**
RESUMO: A escavação arqueológica do forte Orange que, entre seus objetivos, buscou contribuir para a Restauração, trouxe a luz detalhes importantes que até então permaneciam nas brumas de possíveis interpretações de documentos. Um dos mais controversos diz respeito aos construtores e à nomenclatura do forte que, mais recentemente, vem sendo conhecido como Forte Orange, atribuído como de construção holandesa do século XVII. A análise arqueológica dos resultados obtidos com a escavação aponta para a existência sucessiva de dois fortes distintos, ocupando o mesmo espaço em momentos sequentes: o mais antigo, o Forte Orange, em terra, de construção holandesa, e o mais recente, português, a Fortaleza de Santa Cruz, construída em pedras, que se sobrepôs ao primeiro. A restauração privilegiou o forte mais recente, cuja estrutura foi preservada ao longo dos séculos. Neste processo foram levadas em consideração muito do que foi revelado arqueologicamente. Todavia, visando o processo de musealização do Forte, algumas das estruturas holandesas recuperadas através da pesquisa arqueológica foram mantidas à mostra, com base nos relatórios apresentados. A pesquisa arqueológica tomou o cuidado de manter preservadas in situ todas as estruturas resgatadas, de modo que, no presente ou de futuro, todas elas possam vir a ser postas a mostra, integrando o acervo do Forte.

Palavras-chaves: Forte Orange, Fortaleza de Santa Cruz, Arqueologia de Fortificação, Holandeses no Brasil

ABSTRACT: The archaeological excavation of the Fort Orange, which among its objectives sought to contribute to the restoration, brought light important details that until then remained in the mists of possible interpretations of documents. One of the most controversial concerns the builders and the nomenclature of the fort, which most recently has been known as Forte Orange, attributed as a Dutch construction of the 17th century. The archaeological analysis of the results obtained with the excavation points to the successive existence of two distinct strengths, occupying the same space in sequent moments: The oldest, the Fort Orange, on land, of Dutch construction, and the most recent, Portuguese, the Fortress of Santa Cruz, built on stones, which overthrew the first. The restoration privileged the most recent fort, built on stones, whose structure has been preserved over the centuries. In this process were taken into account much of what was revealed archaeologically. However, aiming at the musealization process of the fort, some of the Dutch structures recovered through archaeological research were kept on display, based on the reports presented. The archaeological research took care to keep preserved in situ all the structures rescued, so that, in the present, or in the future, all of them can be put to show, integrating the collection of the fort.

Keywords: Fort Orange; Santa Cruz Fortress; Fortification Archaeology; Archaeology and Restoration; The Dutch in Brazil 


\section{Preâmbulo}

A escavação arqueológica do Forte Orange que, entre seus objetivos, buscou contribuir para a Restauração, trouxe a luz detalhes importantes que até então permaneciam nas brumas de possíveis interpretações de documentos. Um dos mais controversos diz respeito aos construtores e à nomenclatura do forte que, mais recentemente, vem sendo conhecido como Forte Orange, atribuído como de construção holandesa do século XVII.

A análise arqueológica dos resultados obtidos com a escavação aponta para a existência sucessiva de dois fortes distintos, ocupando o mesmo espaço em momentos sequentes: o mais antigo, o Forte Orange, em terra, de construção holandesa, e o mais recente, português, a Fortaleza de Santa Cruz, construída em pedras, que se sobrepôs ao primeiro.

Com base na pesquisa arqueológica pode-se afirmar que a construção do forte em pedras não "encamisou" o forte holandês, em terra, como alguns autores descreveram. Sobrepôs-se a ele, em parte, mas suas dimensões excederam às do forte holandês. Conhecidos através da iconografia coeva, as semelhanças entre os traçados de ambos os fortes, que se mostram regulares, com quatro baluartes e mantendo a mesma orientação em relação à costa, contribuiu para a suposição de que a construção portuguesa houvesse revestido em pedras o forte holandês, o que de fato não se deu, como ficou demonstrado com a pesquisa arqueológica. Apenas em uma das faces, aquela voltada para o Canal de Santa Cruz, as cortinas dos dois fortes se sobrepõem em parte. O mesmo já não se pode afirmar quanto aos baluartes contíguos a ela. Também as estruturas internas, quartéis, casa de pólvora e cacimba do antigo forte holandês, não foram reaproveitados no forte português. Nem mesmo a porta de acesso foi mantida na posição original. Enquanto que o acesso ao forte holandês fora voltado para o Canal de Santa Cruz, o acesso ao forte português fora voltado para o interior da ilha.

Parte das estruturas holandesas permaneceram no contexto arqueológico e foram resgatadas através da pesquisa arqueológica; também foram postas a mostra estruturas do forte português que se encontravam total ou parcialmente ocultadas pelas areias que se depositaram ao longo do tempo. Diferentes questões envolvendo antigas restaurações e mesmo estruturas que teriam ou não sido concluídas, foram analisadas à luz da pesquisa arqueológica, atendendo a demandas do Iphan. Muitos foram os relatórios que 
trataram de questões específicas como, por exemplo, a distribuição das 'bocas de fogo' do forte português, com base nas plataformas construídas para os canhões.

Dentre os relatórios específicos apresentados, um deles, o "Relatório resumido, referente às estruturas encontradas na escavação arqueológica, que podem apoiar o projeto de restauração e utilização", buscou fornecer subsídios ao projeto de restauração do Forte.

A restauração privilegiou o forte mais recente, construído em pedras, cuja estrutura foi preservada ao longo dos séculos. Nesse processo foram levadas em consideração muito do que foi revelado arqueologicamente. Todavia, visando o processo de musealização do Forte, algumas das estruturas holandesas recuperadas através da pesquisa arqueológica foram mantidas à mostra, com base nos relatórios apresentados.

A pesquisa arqueológica manteve preservadas in situ todas as estruturas resgatadas, de modo que, no presente ou de futuro, todas elas possam vir a ser postas a mostra, integrando o acervo do Forte.

\section{Introdução}

O Forte Orange se mostrou, como sítio arqueológico, bem mais rico do que se ousava esperar, tendo em vista toda a documentação de suas reformas e das frequentes fases de quase destruição por que passou. Esteve ainda, durante o longo abandono que sofreu, a mercê de "caçadores de tesouros" e de "sonhadores de botijas", mas, nas suas areias ficaram preservados testemunhos de suas diferentes fases. Assim é que foi possível, mediante uma escavação arqueológica sistemática e abrangente, conhecer-se muitos aspectos de suas diferentes fases.

Da fase mais antiga, resgataram-se trechos da primeira muralha do forte holandês, construída em terra, com parapeitos protegidos por uma defesa em madeira. Ainda da fase holandesa, conhece-se agora, através dos alicerces em pedra resgatados, os quartéis interiores ( 5 conjuntos), a casa de pólvora, a porta de acesso ao forte, voltada para o canal de Santa Cruz, e ainda o poço que abastecia o forte.

Em fase posterior, durante a ocupação luso-brasileira, o forte foi alvo de seguidas reformas. Mas nem sempre o planejamento apresentado por meio das plantas foi executado ou talvez, dentre várias propostas, apenas uma teria sido concretizada. Desde 
cedo dentre as construções interiores, incorporou-se uma capela. Pretendeu-se construir uma 'mais digna' sobre o trânsito, mas, na realidade, apenas se ampliou a antiga capela, onde foram sepultados os mortos ilustres.

Todas estas descobertas foram possíveis graças a uma abordagem ampla e, sobretudo sistemática do sítio arqueológico. Uma abordagem que se reflete no avultado número de $\mathrm{m}^{3}$ de terra escavada e peneirada, com resultados que em muito ultrapassam as expectativas mais otimistas.

É importante observar que o resultado obtido na escavação do Forte Orange não se restringe àquele forte, mas que traz novas perspectivas para o conhecimento acerca das estruturas de defesa holandesas no Brasil, e da evolução das defesas luso-brasileiras ao longo do tempo. Ressalte-se ainda que do ponto de vista do interesse, tanto científico quanto da restauração e da musealização, as peças encontradas oferecem um forte potencial para exposição.

\section{Escavação da Praça de Armas}

A escavação da praça de armas concernente ao período luso-brasileiro permitiu reconhecer que, além dos quartéis dispostos junto à contra-muralha, a única estrutura presente naquele pátio foi a cacimba que abastecia (e continua abastecendo) o forte. Escavada na areia, com as paredes revestidas em tijolos batidos, embora de pouca profundidade, se mostra de rápida recuperação quando esgotada, fornecendo água cuja salinidade não excede os padrões apontados pelos órgãos internacionais atuais, como de qualidade potável. Trata-se de uma praça de armas ampla, destituída de estruturas interiores, exceto, como foi referido, pela presença da cacimba, equidistante dos quartéis que ladeiam a praça e das rampas de acesso ao terrapleno. Os quartéis, construídos a partir das contra-muralhas, cercavam a praça de armas. Apenas um dos lados não apresentava quartéis justapostos à contra-muralha. Certamente, como apontam as "esperas" deixadas, não chegaram a ser construídos, mas foram planejados.

A escavação arqueológica daquela área permitiu ainda reconstituir-se grande parte da antiga praça de armas do período holandês. Nesta feição o interior do forte, cujas defesas externas foram construídas em terra, apresentavam estruturas internas construídas em pedra, rebocadas e caiadas (Figura 1). 
Diferentemente dos quartéis do período luso brasileiro, os quartéis e a casa de pólvora eram isolados, não se integrando às defesas externas. Ao todo foram realizados 136 cortes na praça de armas.

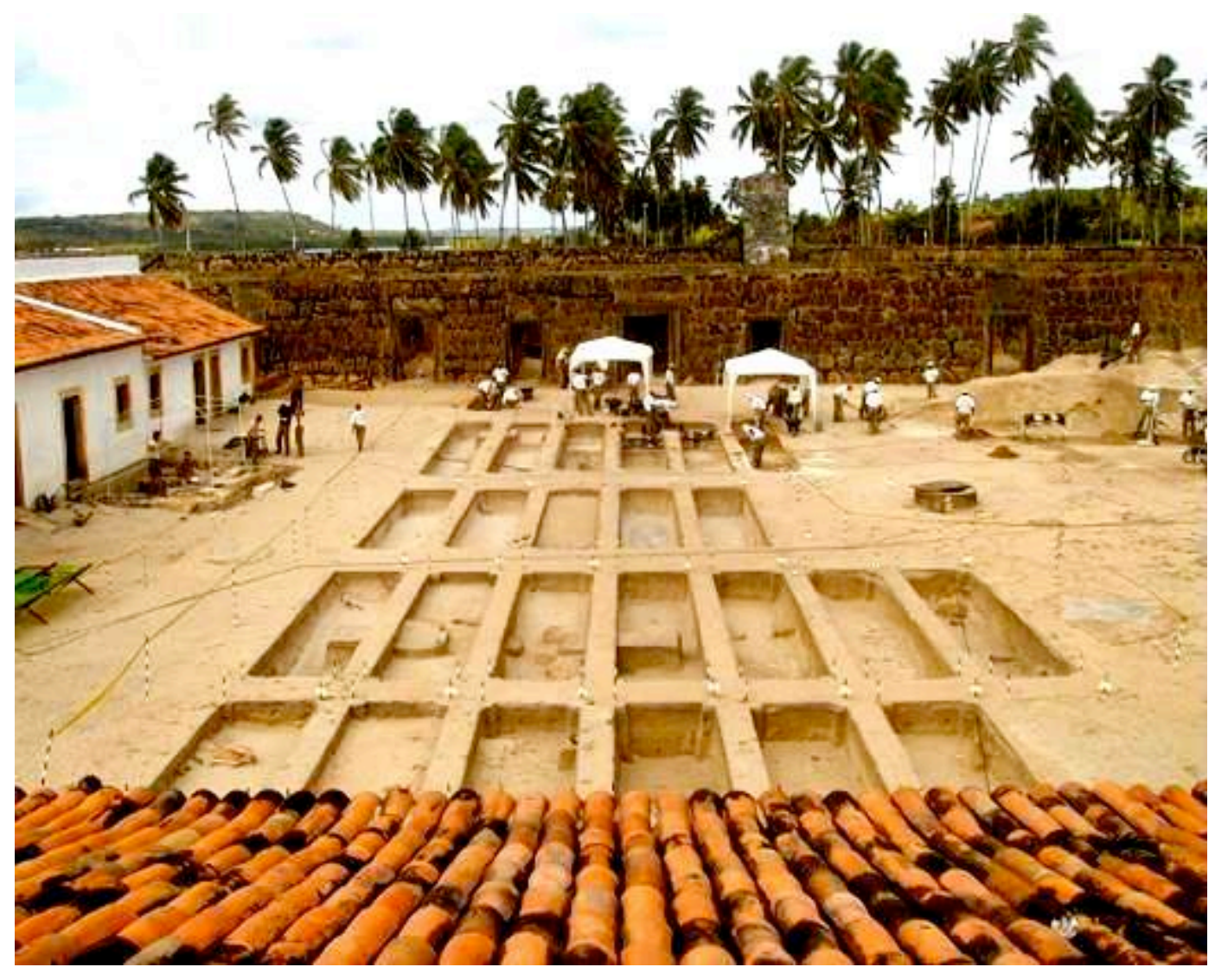

Figura 1: Vista parcial da escavação da praça de armas, em que se pode apontar a cacimba (no centro à direita). Foto: Doris Walmsley, 2003.

Estruturas concernentes ao Forte Orange (holandês) resgatadas arqueologicamente e preservadas in situ, que podem vir a ser incorporadas ao acervo a ser exposto ao público

Foram encontrados remanescentes vestigiais de estruturas da $1^{\text {a }}$ metade do século XVII, resultantes da demolição de quartéis e outras unidades funcionais correspondentes ao período de ocupação holandesa (Figura 2). 


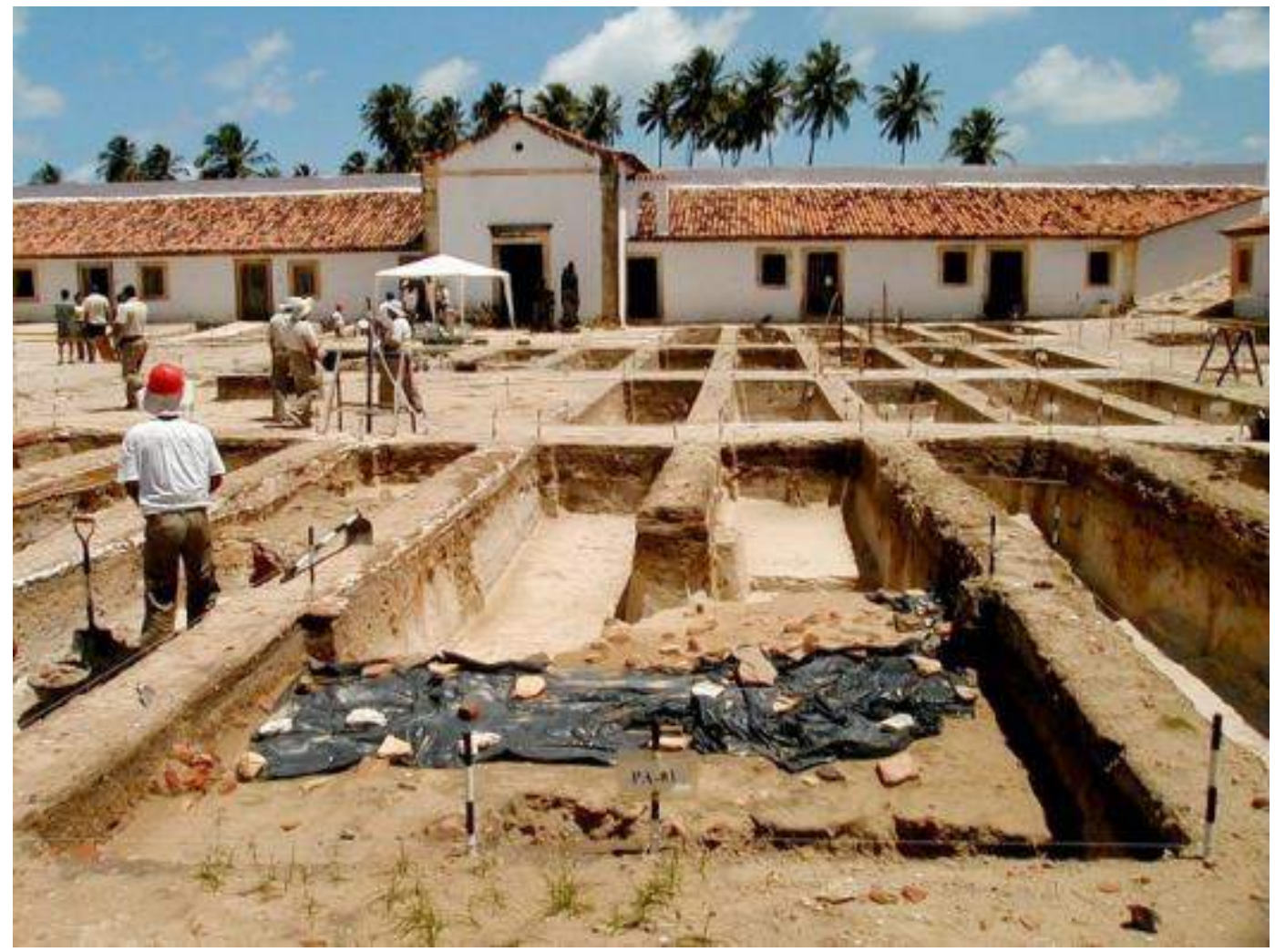

Figura 2: Vista parcial dos cortes escavados na praça de armas. Foto: Doris Walmsley, 2003.

Quartéis holandeses no interior do forte. Localização e constituição

Comparados os achados à iconografia coeva, bem como às técnicas construtivas utilizadas no período, foi possível identificar cinco conjuntos de quartéis que integravam o forte holandês, utilizado durante a administração de Nassau. Quartéis construídos em pedra (calcário e arenito), obtida nas proximidades da llha.

Os quartéis foram demolidos e as pedras provavelmente reaproveitadas durante a construção do forte português. Restou grande parte das pedras do alicerce o que permitiu reconstituir o seu traçado. É importante observar que a técnica de construção empregada no alicerce prescindiu o uso de material cimentante. Foram abertas trincheiras, nas quais foram assentadas pedras, bem ajustadas entre si, sendo as lacunas preenchidas com argila e areia (Figura 3 e 4). 


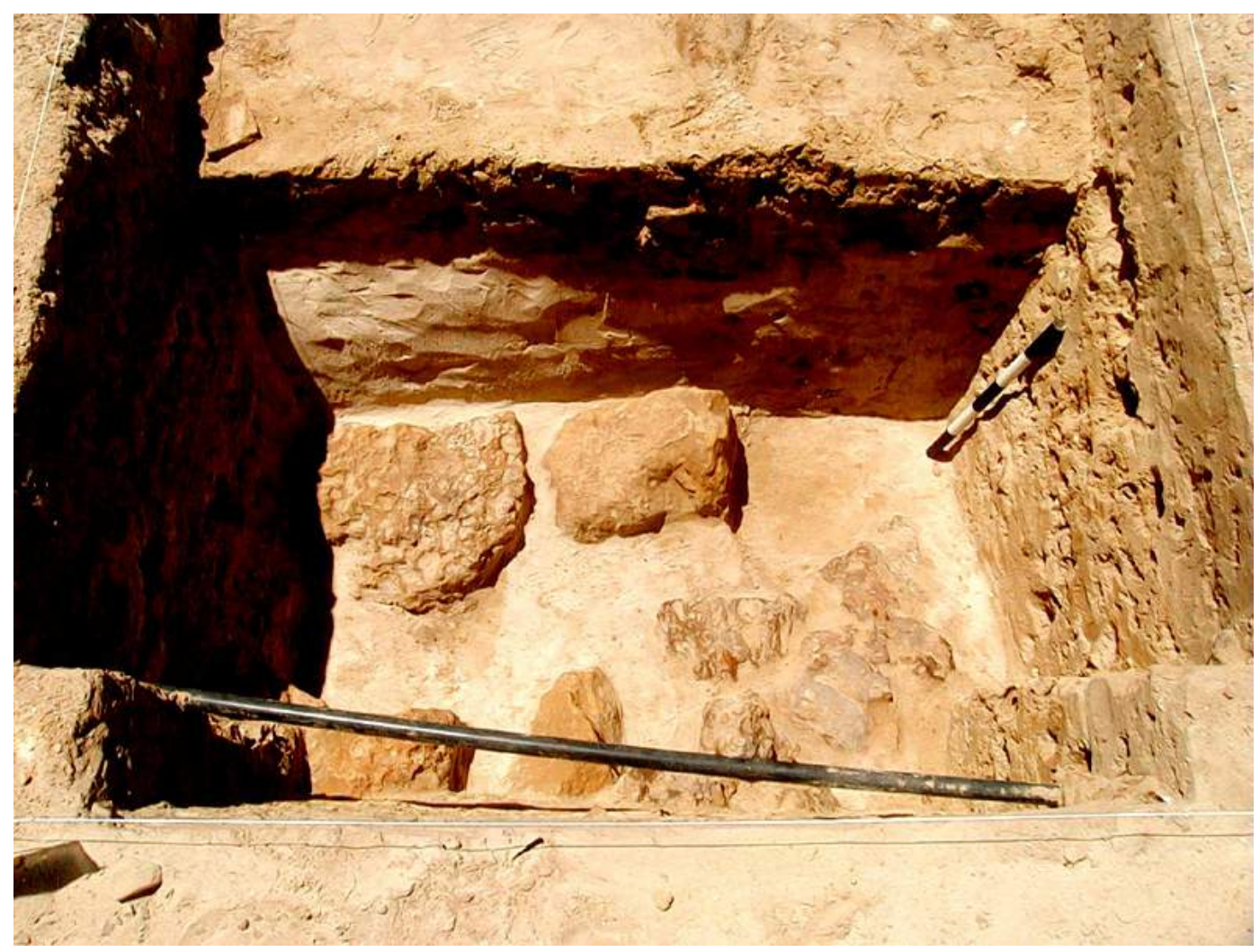

Figura 3: Remanescentes dos alicerces dos quartéis holandeses. Foto: Doris Walmsley, 2003.

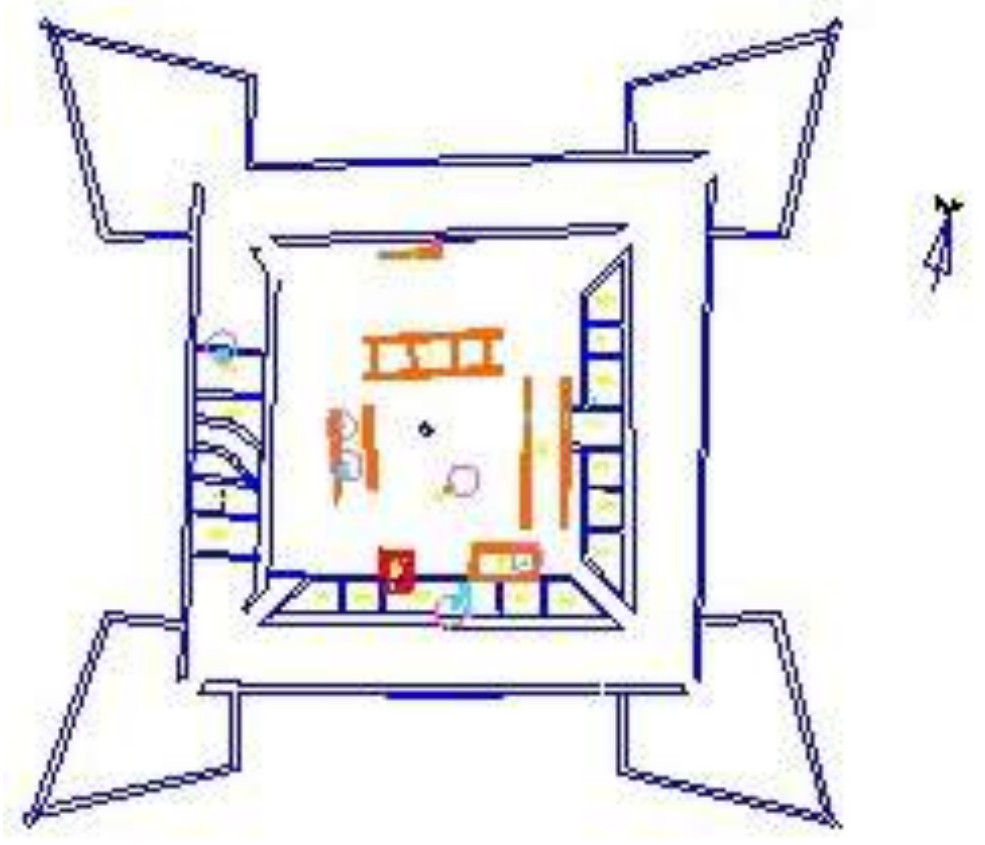

Figura 4: Planta do forte luso-brasileiro (azul) e as estruturas holandesas em seu interior (em laranja), quartéis, casa de pólvora e cacimba. 
Sobre a iconografia do forte holandês estão assinalados os alicerces encontrados. Nesta figura as dimensões não correspondem exatamente às medidas. Também a localização é aproximada, apenas para exemplificar a distribuição. Disposição e dimensões exatas dos achados na planta abaixo e em arquivo digital (Figura 4).

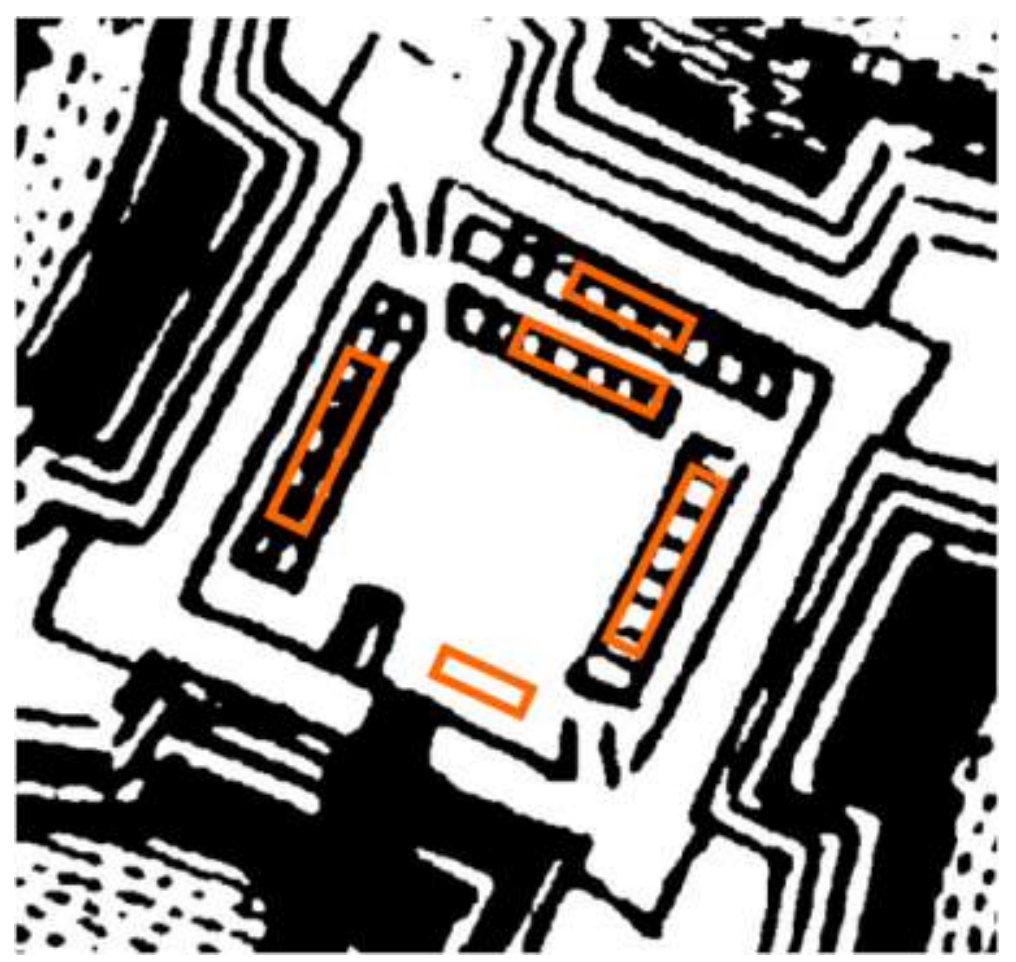

Figura 5: Iconografias coevas, holandesas, mostrando o interior do Forte Orange e seus quartéis. Sobreposto (em laranja) as fundações localizadas. Fonte: Albuquerque, 2004

Os quartéis com suas paredes de pedra rebocadas e caiadas de branco eram cobertos com telhas (Figura 6). 0 piso dos quartéis foi revestido, em sua maioria, com tijolos de barro vermelho (Figura 7). Um dos quartéis teve o piso, pelo menos em parte, revestido com os pequenos tijolos holandeses amarelos (Figura 9). Vestígios de parte dos pisos dos quartéis foram localizados e se encontram preservados no interior da atual praça de armas. 


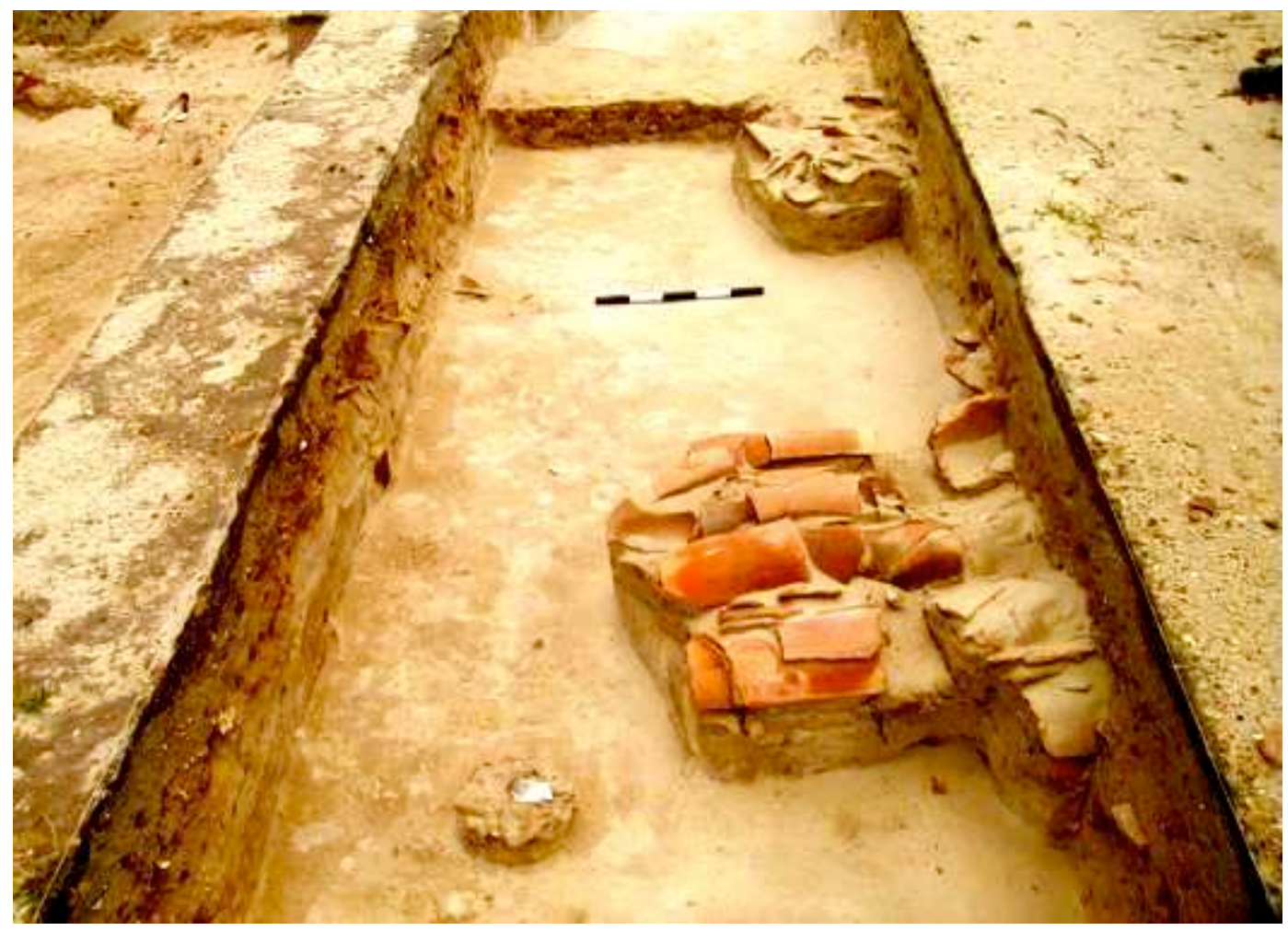

Figura 6: Grande quantidade de telhas foi encontrada na camada relacionada à demolição dos quartéis holandeses. Foto: Doris Walmsley, 2003.

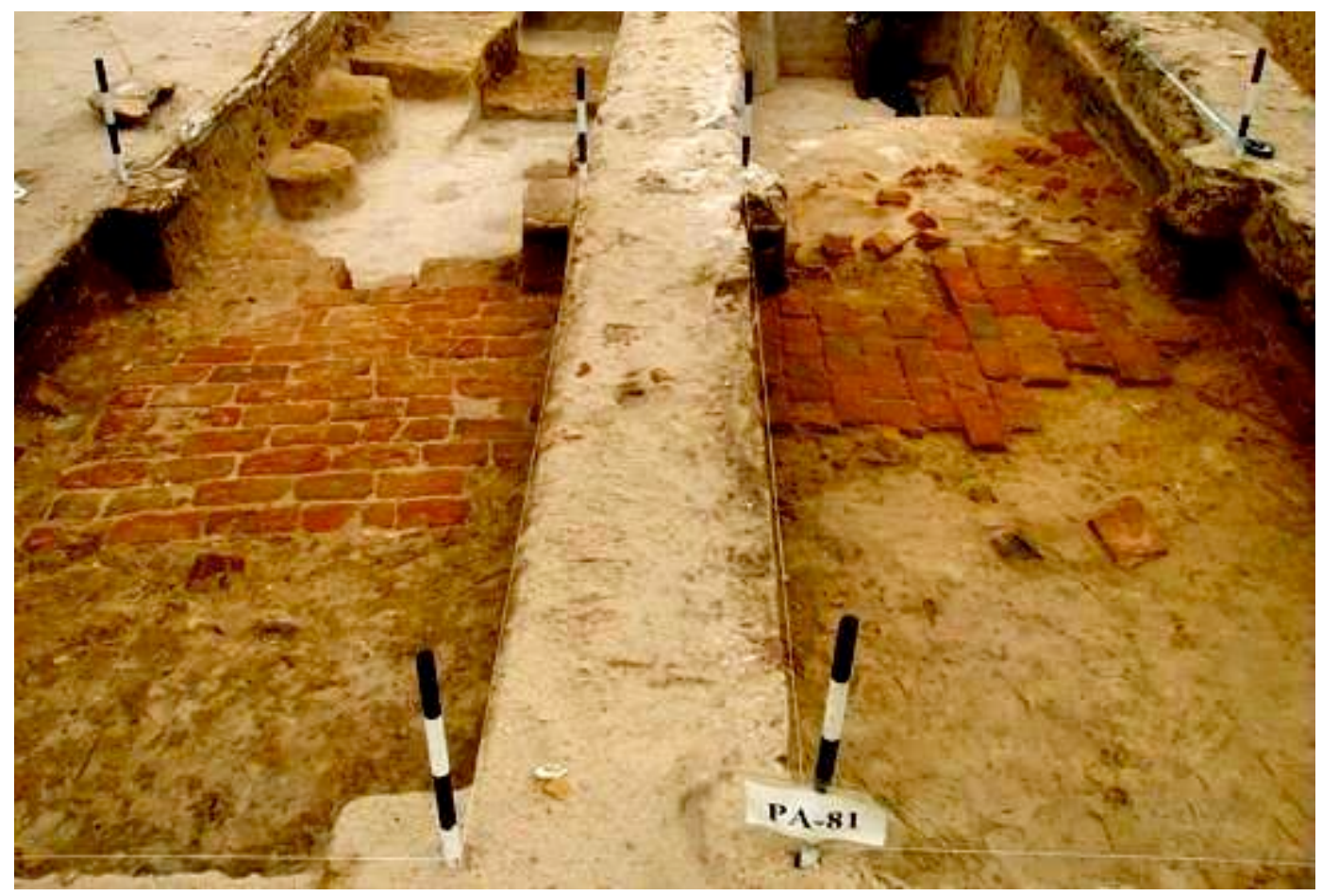

Figura 7: Parte dos antigos pisos de dois cômodos de quartéis holandeses, revestidos com tijolos. Foto: Doris Walmsley, 2003. 


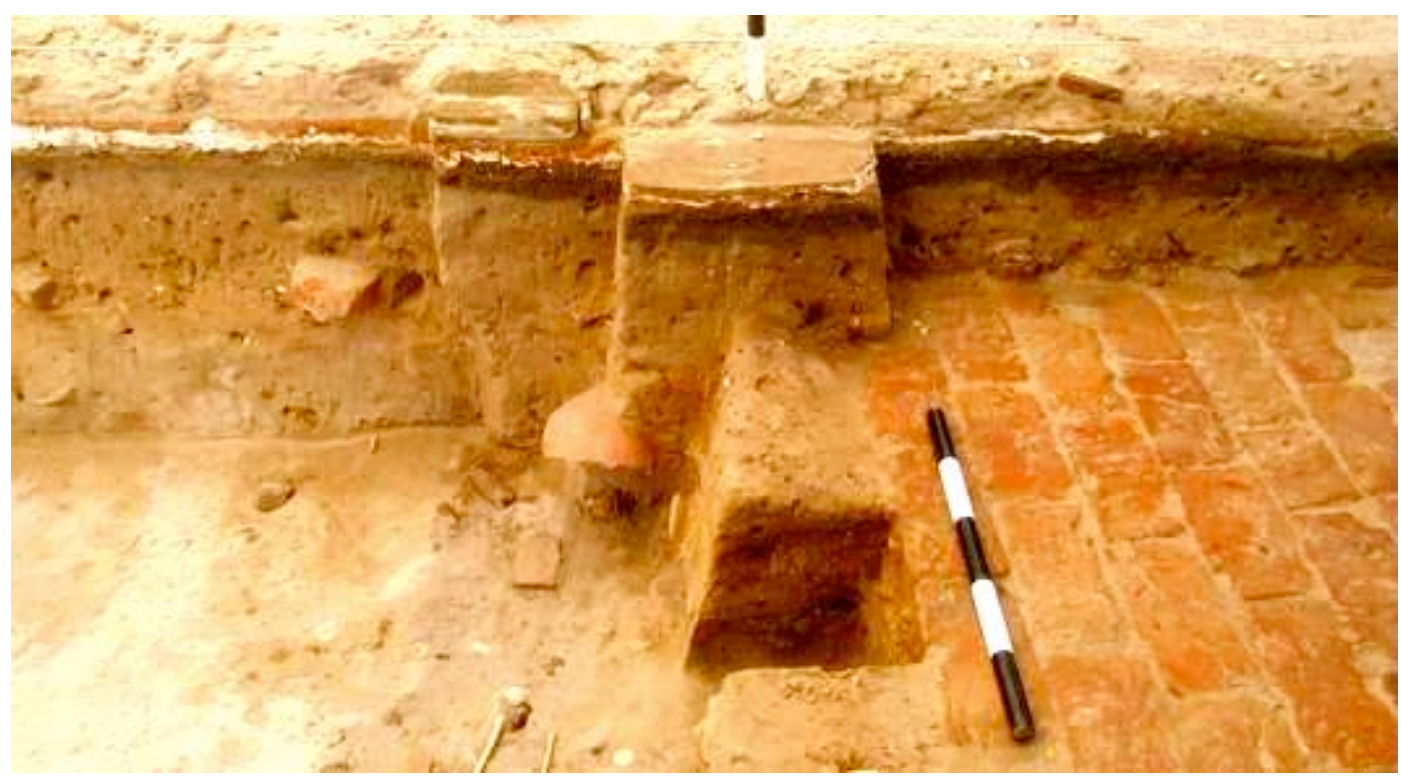

Figura 8: Seção de um dos quartéis, com o piso em tijolos. Foto: Doris Walmsley, 2003.

Pelo menos parte dos alojamentos dispunha de seu próprio fogo. Em Itamaracá, a prática holandesa da preparação de alimentos em pequenos grupos de soldados, em seus próprios alojamentos, parece ter sido seguida. Coadunava-se com a prática de distribuição de quotas individuais de alimentos a ser preparado, e mesmo, como ocorrera em certas ocasiões de escassez, com o pagamento de parte do soldo com alimentos.

Em um dos quartéis, paralelo à casa de pólvora, foi localizado e preservado os restos de um desses "fogões" (Figura 9).

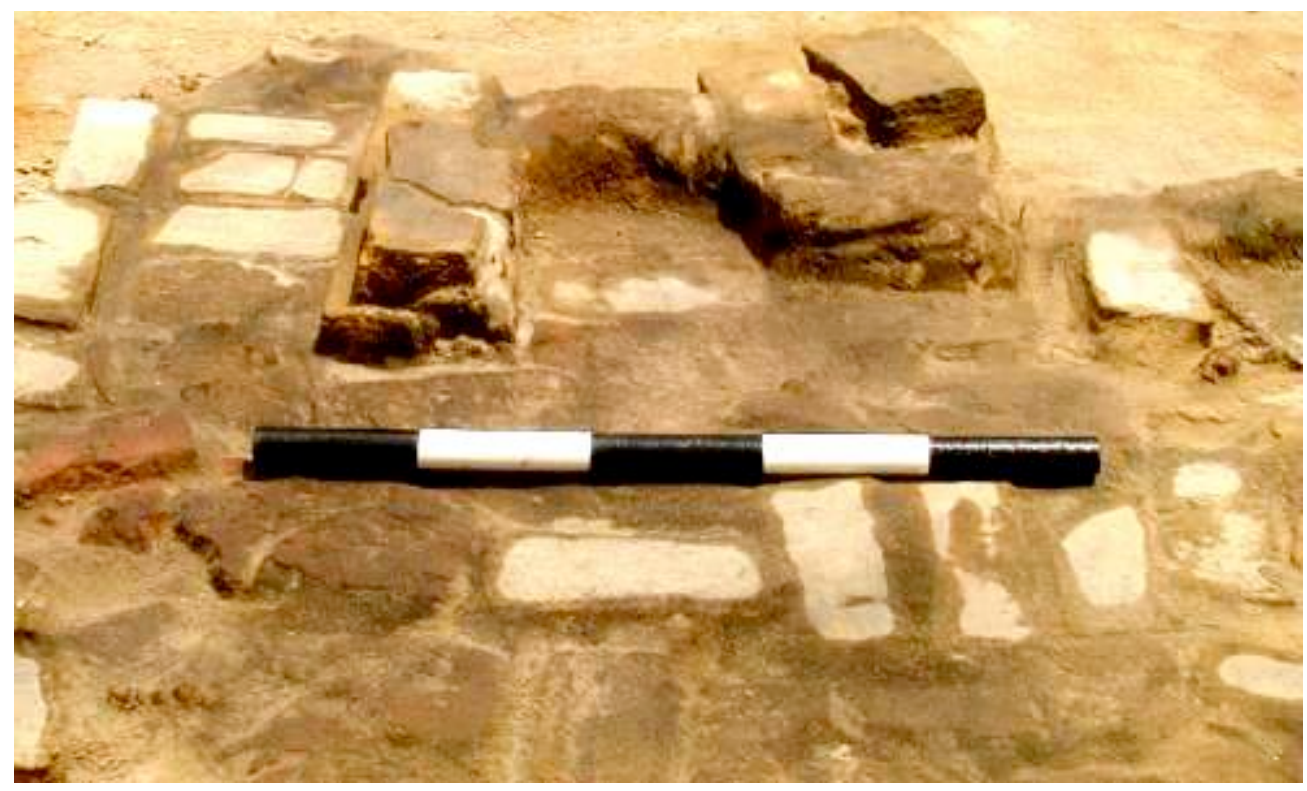

Figura 9: Restos de um antigo fogão à lenha, encontrado em uma das extremidades de um cômodo dos quartéis holandeses. Foto: Doris Walmsley, 2003. 


\section{A antiga cacimba que serviu ao forte durante o período de ocupação holandesa}

A cacimba construída pelos holandeses ocupava aproximadamente o centro da praça de armas de então (Figura 10).

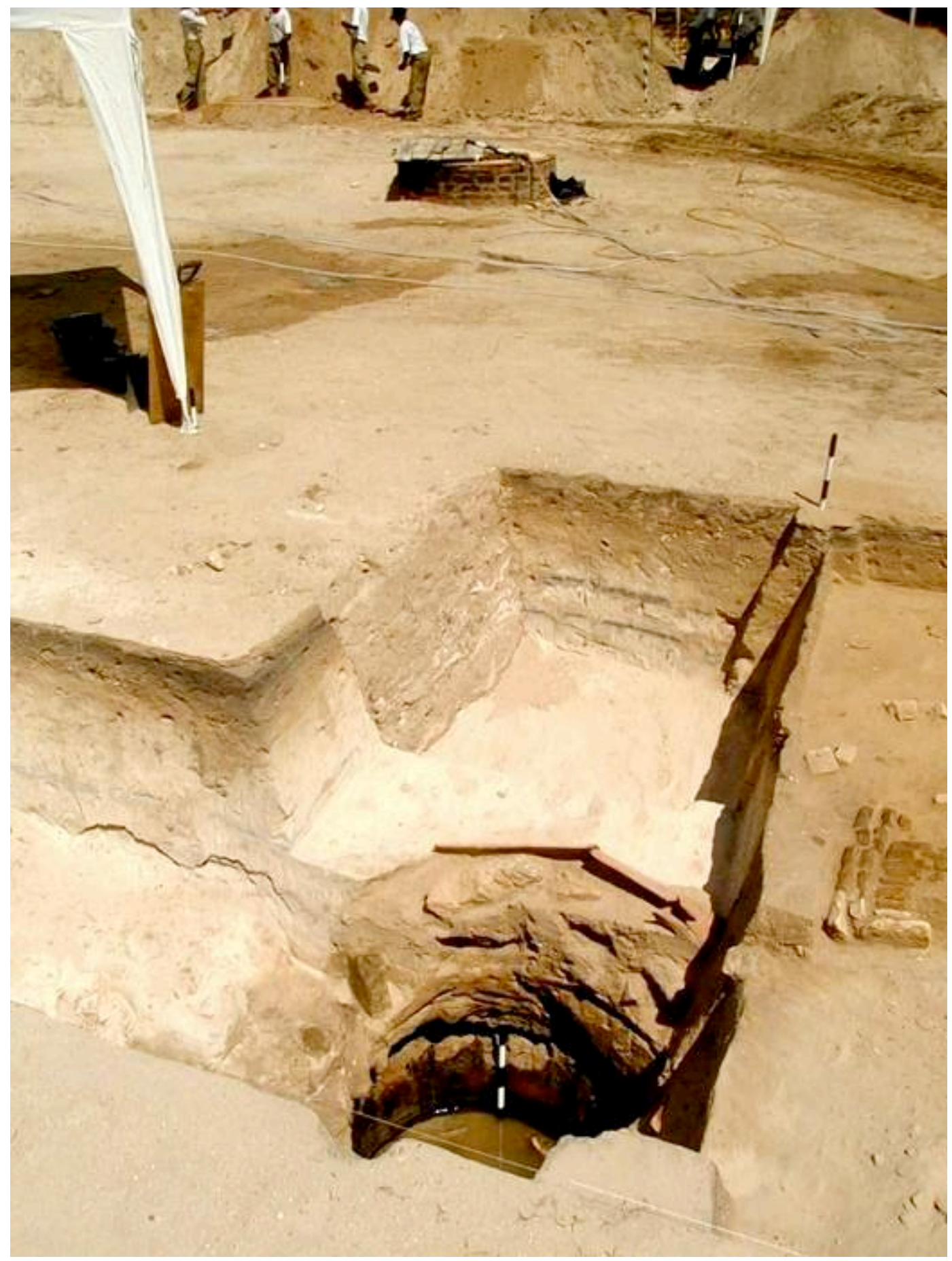

Figura 10: Vista da praça de armas atual vendo-se, em primeiro plano, a antiga cacimba holandesa e, ao fundo, a cacimba construída no século XVIII. Foto: Doris Walmsley, 2003. 
A técnica de construção empregada nessa cacimba difere das técnicas observadas nas demais cacimbas até então conhecidas nos fortes estudados arqueologicamente no Brasil. A abertura de uma cacimba naquele terreno arenoso, de areias muito soltas, carecia de uma estrutura de contenção que mantivesse aberto o espaço de acumulação das águas. 0 solo constituído por areia, não comportava uma cacimba sem paredes revestidas (Figura 11).

A tradição de uso mais frequente entre a população luso-brasileira de então (e que se prolongou através dos séculos) sinalizava para o uso de tijolos ou pedras revestindo internamente a cacimba.

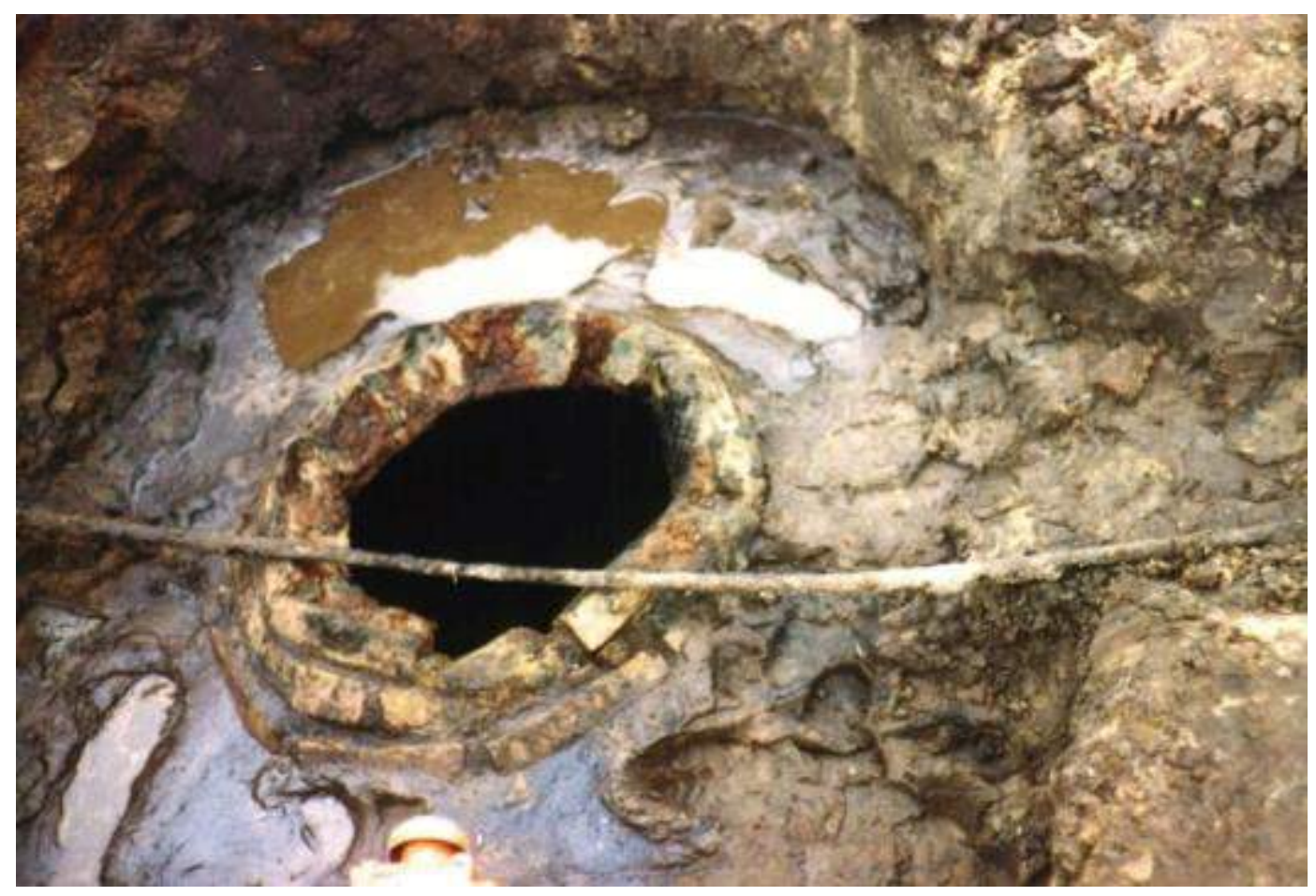

Figura 11: Cacimba escavada em sítio arqueológico na Holanda. A técnica e materiais empregados são os mesmos identificados na cacimba descoberta no Forte Orange, durante a escavação arqueológica. Foto cedida pelo Dr. Hans van Westing, 2002.

Na Holanda, entretanto, havia outra tradição, que também atravessaria os séculos. O uso de grandes barricas ${ }^{1}$ que enterradas e com o interior vazio, constituía-se em uma fonte para captação de água. E esta foi a técnica utilizada na construção daquela antiga cacimba (Figuras 12 e 13).

\footnotetext{
${ }^{1}$ Tonel de madeira, bojudo, feito de aduelas, geralmente para conservar ou transportar líquidos.
} 


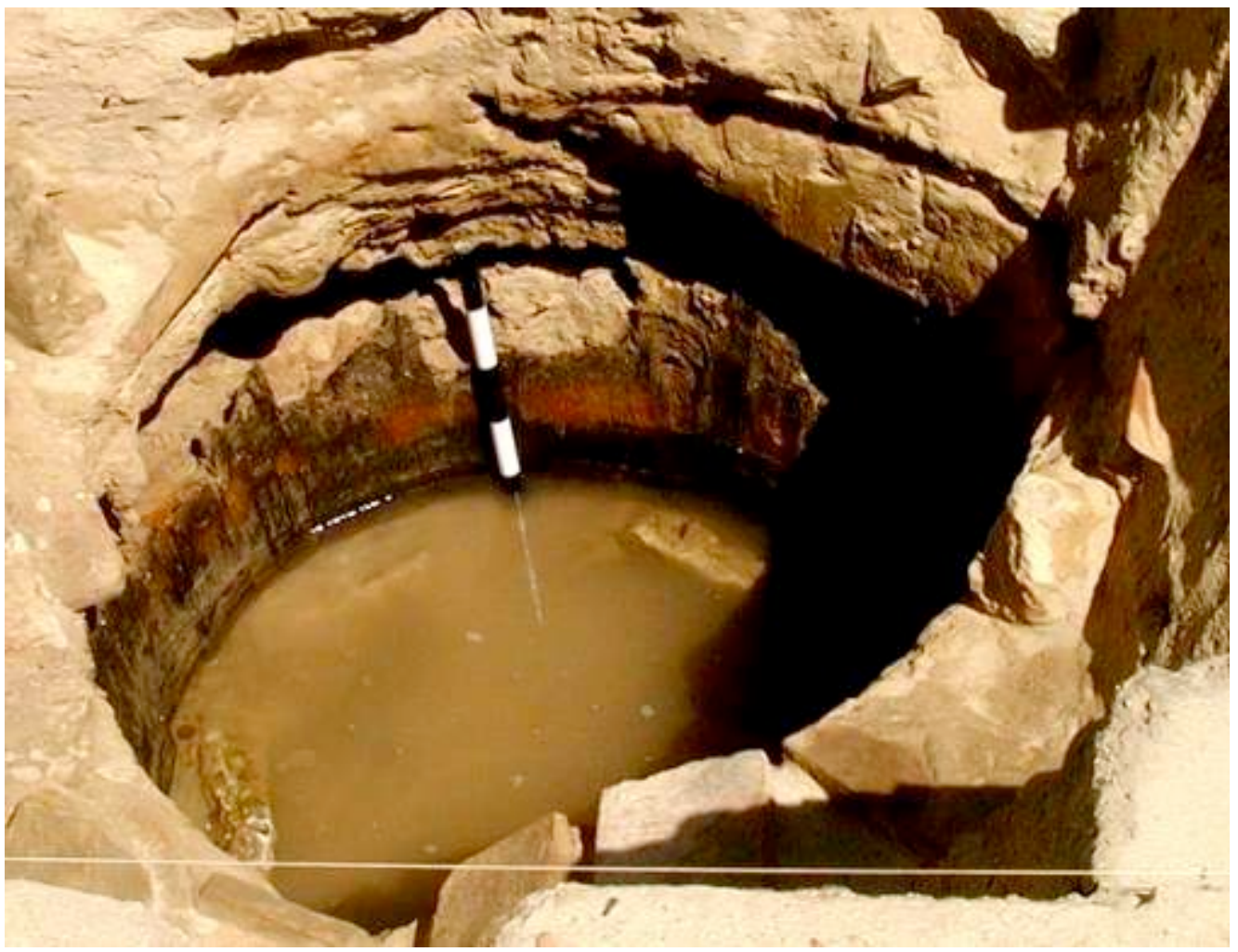

Figura 12: Detalhe do interior da cacimba holandesa, revestida internamente por um barril. Observem-se as dornas conservadas no limite do nível freático. Foto: Doris Walmsley, 2003.

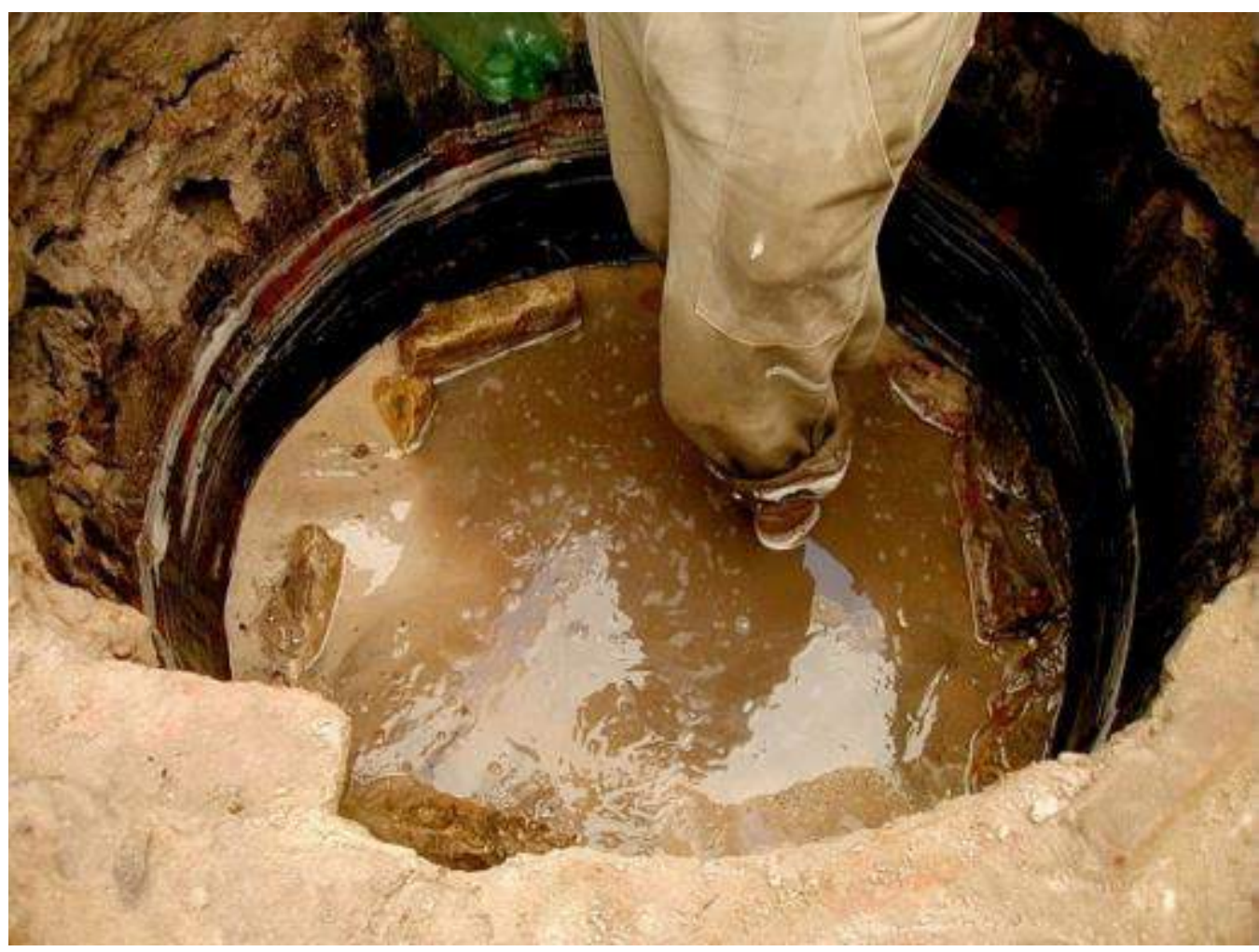

Figura 13: Observe-se o conjunto de pedras calcárias colocadas sob o barril, começam a ser vistas quando se retira a água. Foto: Doris Walmsley, 2003. 
No fundo, a barrica repousava sobre um anel construído com pedras calcárias (Figura 14).

Lateralmente, na porção superior, o vazio gerado para a passagem do barril, foi preenchido com tijolos vermelhos (Figura 15).

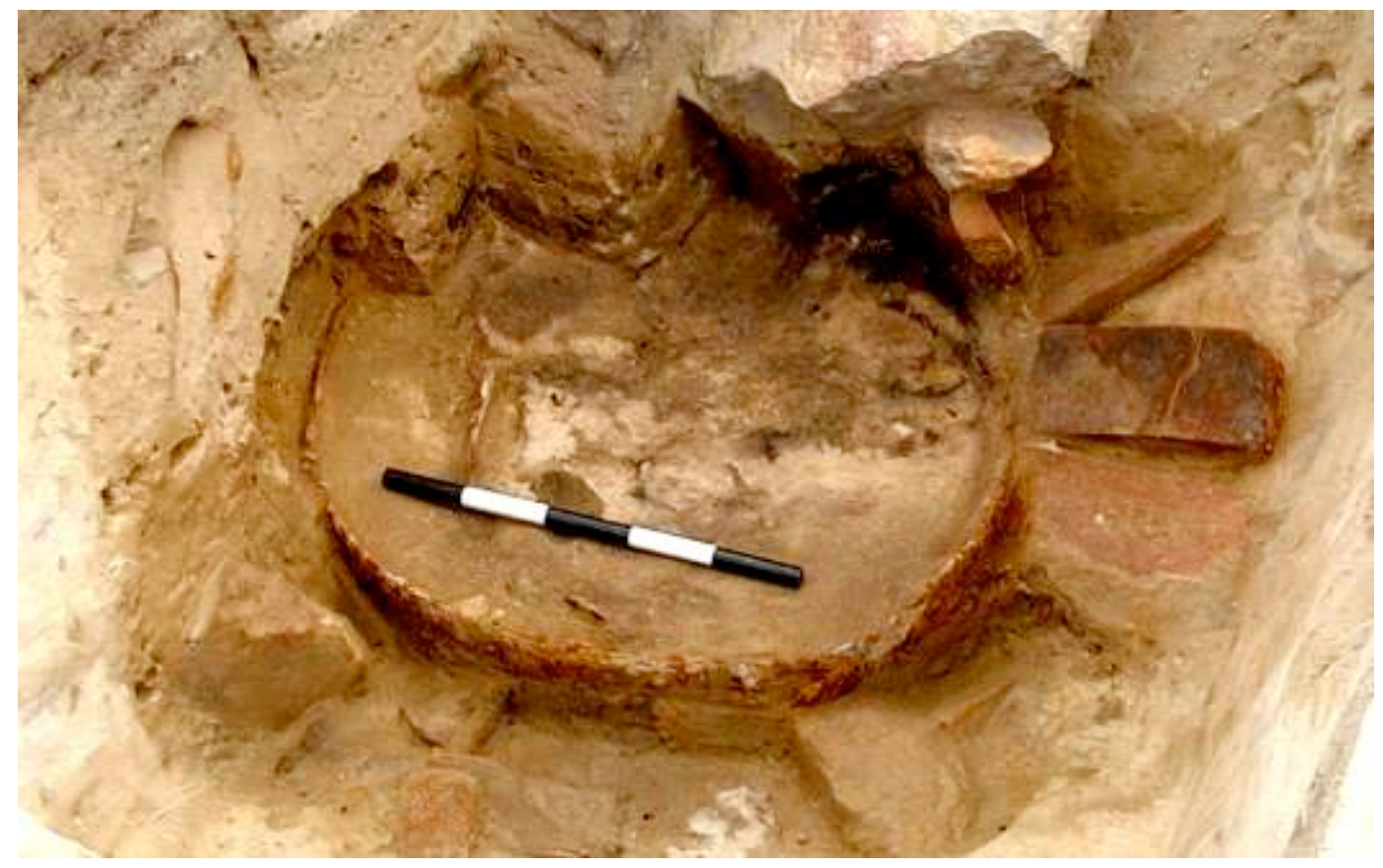

Figura 14: Início da escavação da cacimba holandesa, vendo-se o aro do barril e os tijolos suportando externamente a estrutura. Foto: Doris Walmsley, 2003.

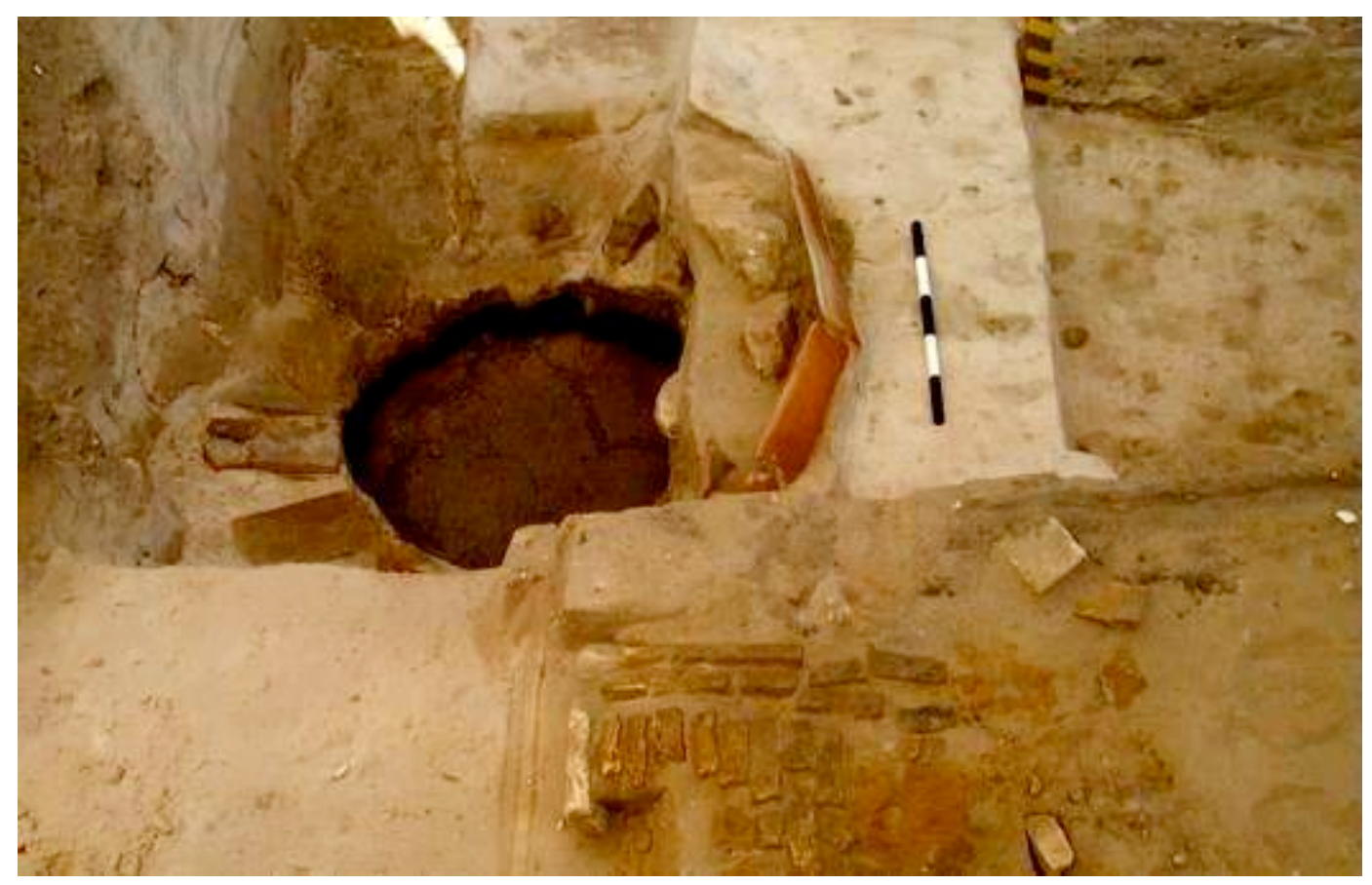

Figura 15: Observe-se, em planos diferentes, a cacimba (cuja parte superior foi destruída) e o remanescente do piso em tijolos que se distribuia em torno da cacimba. Foto: Doris Walmsley, 2003. 
Dominando aproximadamente o centro da praça de armas, o entorno da cacimba fora pavimentado com os pequenos tijolos amarelos trazidos da Holanda (Figura 16). Aquela cacimba continuou a ser utilizada pelos luso-brasileiros até pelo menos o início da segunda metade do século XVIII.

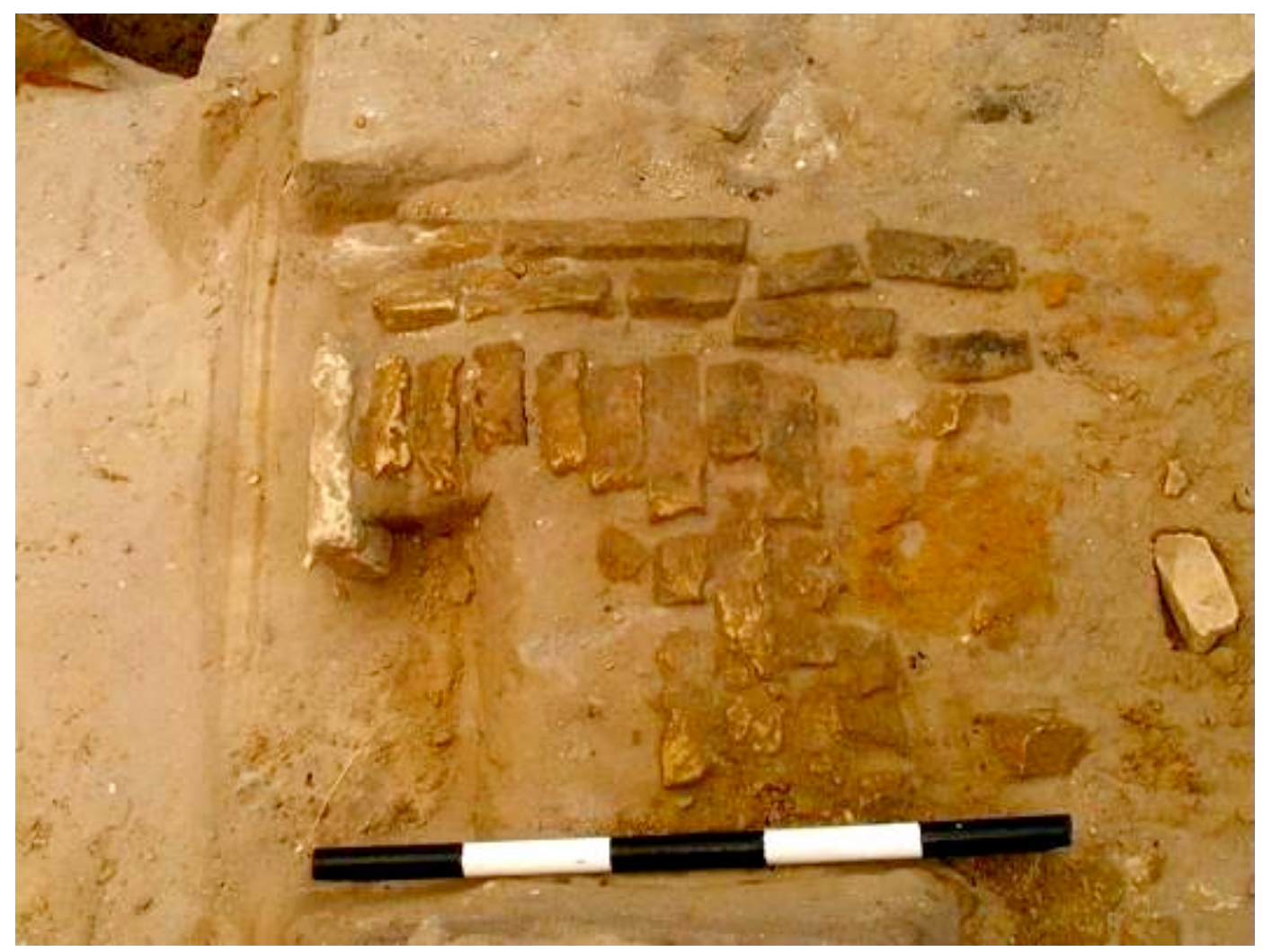

Figura 16: Detalhe do remanescente do piso, em tijolos amarelos. Foto: Doris Walmsley, 2003.

A técnica de uso de barris para revestir cacimbas aplica-se apenas a locais onde o nível do lençol freático seja bastante superficial, onde a profundidade necessária a ser alcançada para a captação da água possa ser atingida por barris. E de fato, a antiga fonte de água do Forte Orange era uma pequena cacimba de $1,04 \mathrm{~cm}$ de diâmetro na boca, atingindo uma profundidade de apenas $2,1 \mathrm{~m}$. O nível freático superficial prescindia um maior aprofundamento da estrutura. Embora de pequenas dimensões, em virtude de sua capacidade de recuperação, era capaz de atender à demanda de uma população relativamente grande. Por outro lado, embora se estivesse muito próximo ao mar, e em uma cota pouco acima das marés, a análise da água revelou uma salinidade relativamente baixa, dentro dos atuais padrões de potabilidade. Certamente muitas e boas fontes de água, eram conhecidas na llha de Itamaracá. Algumas delas assinaladas na cartografia e na iconografia coeva. A qualidade da água dessas fontes haviam mesmo servido de 
argumento quando se elencava as vantagens em transferir-se para Itamaracá a sede do governo holandês, no Brasil. Para aqueles que enfrentavam as travessias marítimas, bebendo regradamente as águas estocadas, quase sempre mal cheirosas e de pior paladar, a água fresca e pura certamente seria um argumento a ser muito considerado. 0 Recife não tinha boa água. Grande parte da água usada no Recife provinha de Olinda. A boa água do Beberibe, que era transportada nas canoas.

Cada fortificação deveria garantir sua própria água; e os que construíram o Forte Orange, embora pudessem apreciar as boas águas das fontes próximas, obrigatoriamente teriam sua própria fonte, que pudesse atendê-los em casos de sítio, ou de combates prolongados.

A cacimba holandesa do Forte Orange, resgatada pela pesquisa arqueológica, foi reaterrada com o objetivo de preservar sua estrutura e permitir que, de futuro, pudesse vir a ser incorporada ao acervo exposto no forte.

\section{A casa de pólvora}

Parte da casa de pólvora já fora localizada desde a prospecção arqueológica realizada em 1970. Embora à época sua concepção fosse uma estrutura construída a céu aberto, o trecho conhecido por meio da pesquisa arqueológica anterior, se encontrava no interior da dependência 12 (Figura 17). Os alojamentos do forte construídos durante a ocupação portuguesa, nos momentos finais das obras, desconsideraram totalmente a casa de pólvora construída pelos holandeses. 


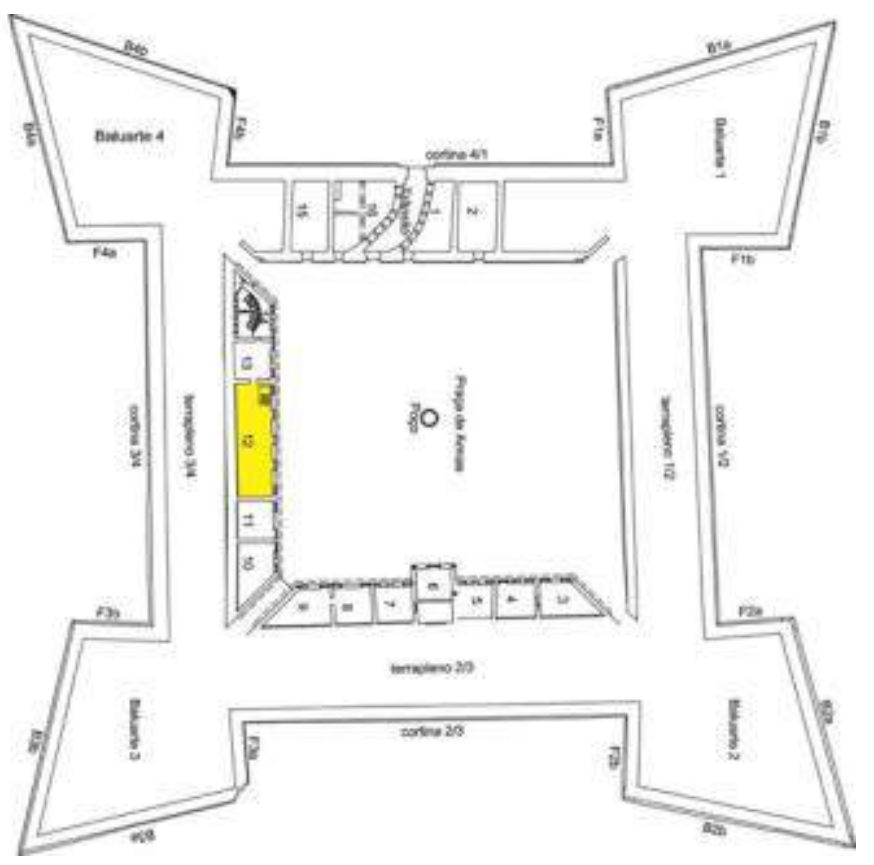

Figura 17: Localização da dependência 12. . Fonte: Albuquerque, 2003

Assim, a parede da fachada da dependência 12 cortou parcialmente a antiga casa de pólvora (Figuras 18 e 19).

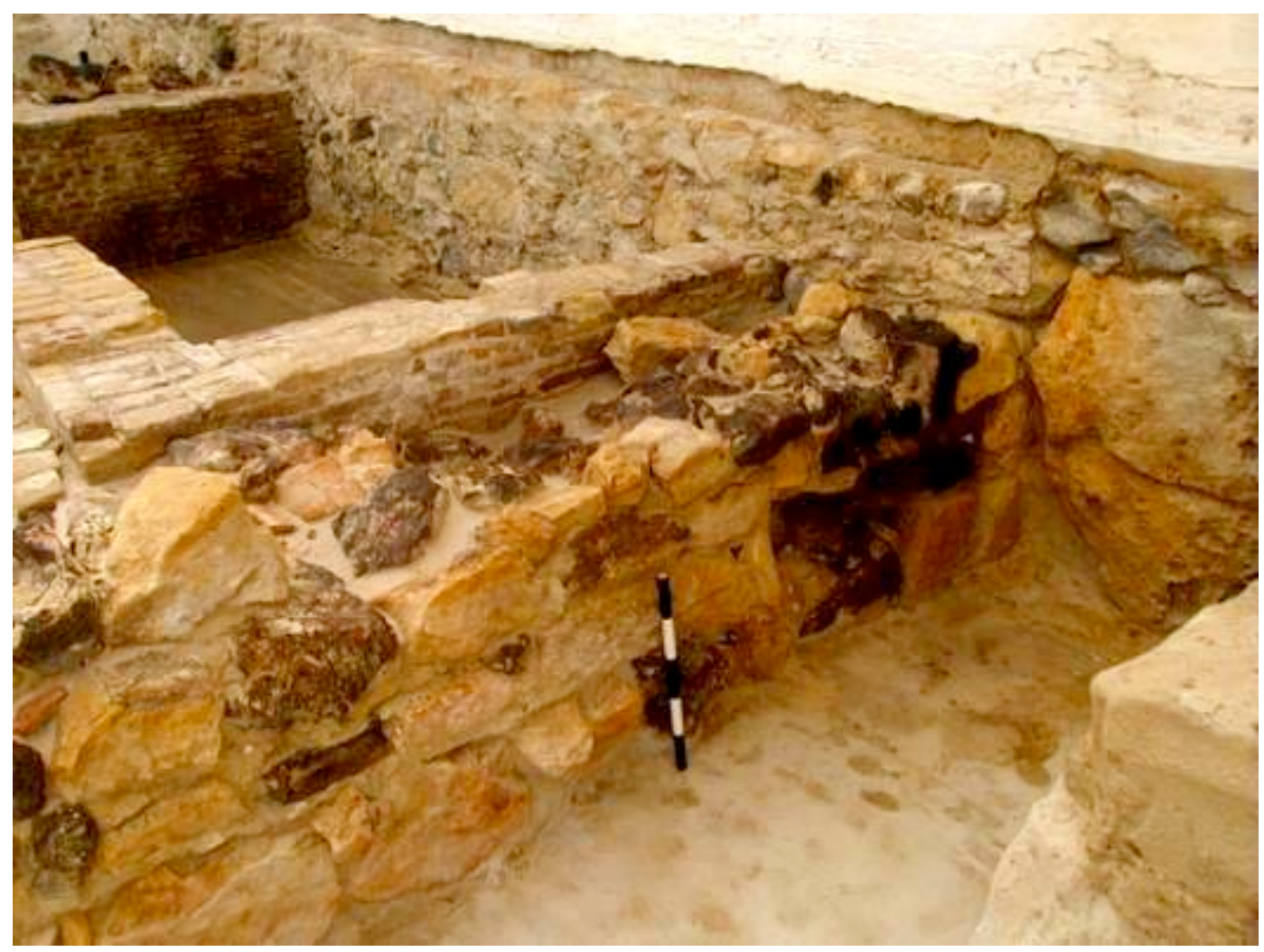

Figura 18: Observe-se a diferença entre o alicerce na área interna e externa à casa de pólvora. . Foto: Doris Walmsley, 2003. 


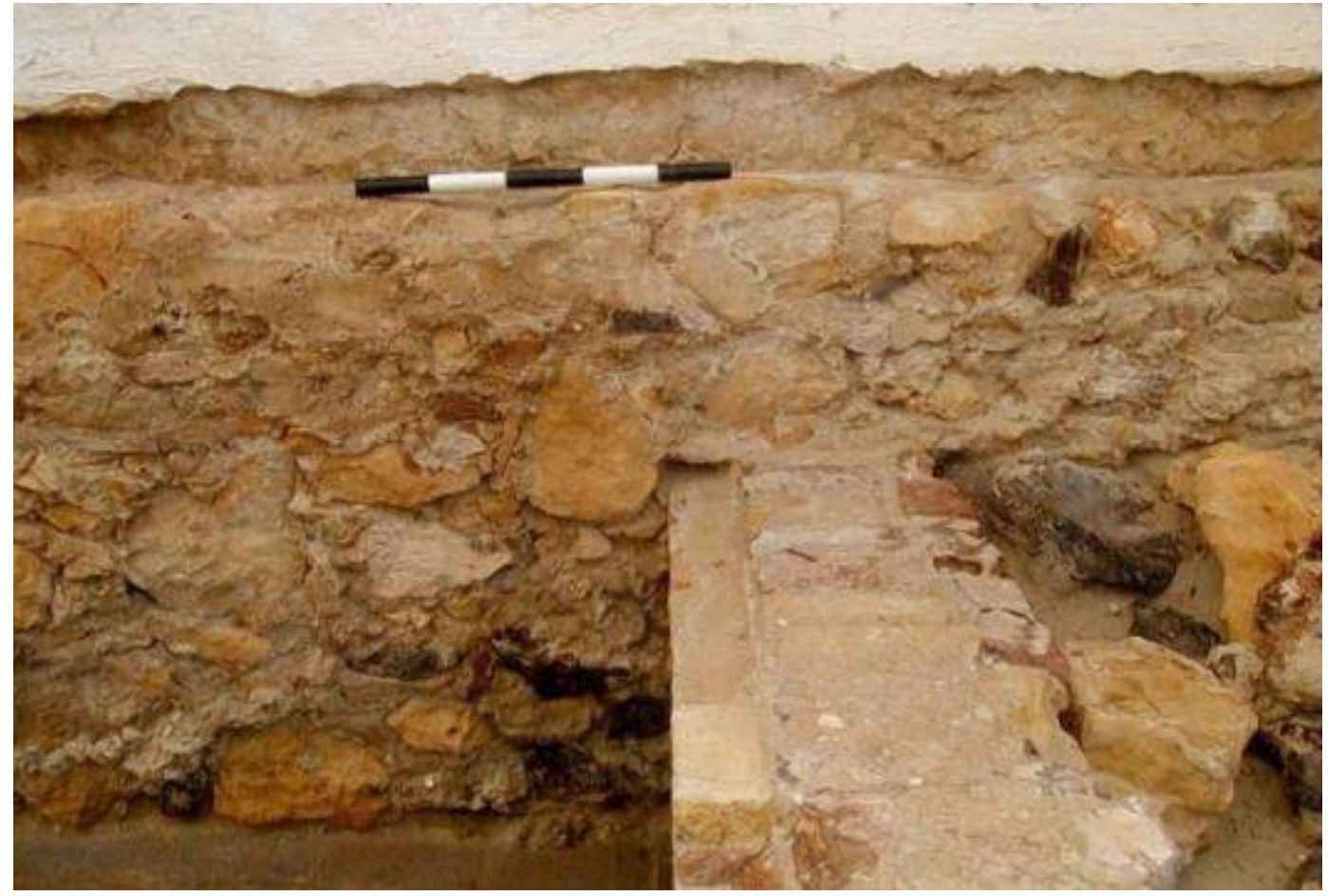

Figura 19: Observe-se que a parede da casa de pólvora prossegue em meio à parede da dependência 12. Foto: Doris Walmsley, 2003.

Entretanto, suas fundações não removeram as estruturas anteriores e a grossa parede de pedras montou por sobre as paredes holandesas em alvenaria de tijolos, bem como por sobre os reforços laterais em alvenaria de pedra. 0 trecho anteriormente localizado foi aquele que se encontrava no interior da dependência 12.

Trechos de suas paredes se encontravam destruídos e foram reconstituídos até a altura então considerada do piso, durante a restauração de 1970-73 (Figura 20). A atual escavação na praça de armas evidenciou a continuidade da estrutura resgatada na praça, com aquele trecho no interior da dependência 12.

Por outro lado, a escadaria construída durante o restauro de $1970-73$, foi removida durante esta pesquisa por se tornar evidente que nunca existira. O conjunto remanescente foi integralmente estudado, tendo revelado inclusive o sistema de acesso, o local e suporte da porta (Figuras 21 e 22). Alguns vestígios sugerem ainda a existência de um antigo piso em madeira, possivelmente com seu forro de carvão, para reduzir a umidade (Figuras 23 e 24). 


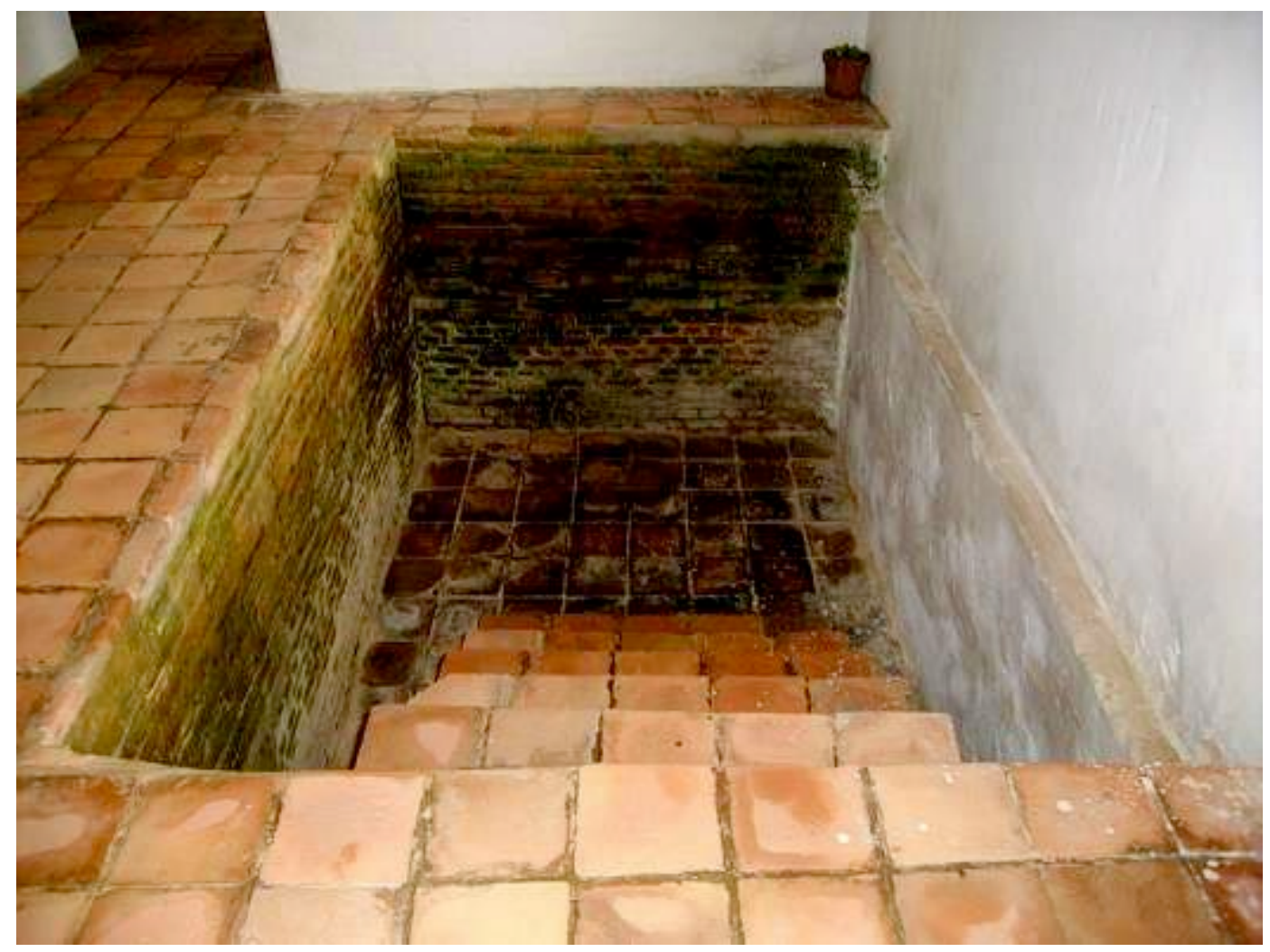

Figura 20: Trecho da casa de pólvora localizado na dependência 12, durante a escavação de 1970 e restaurado em 1973. Foto: Doris Walmsley, 2002.

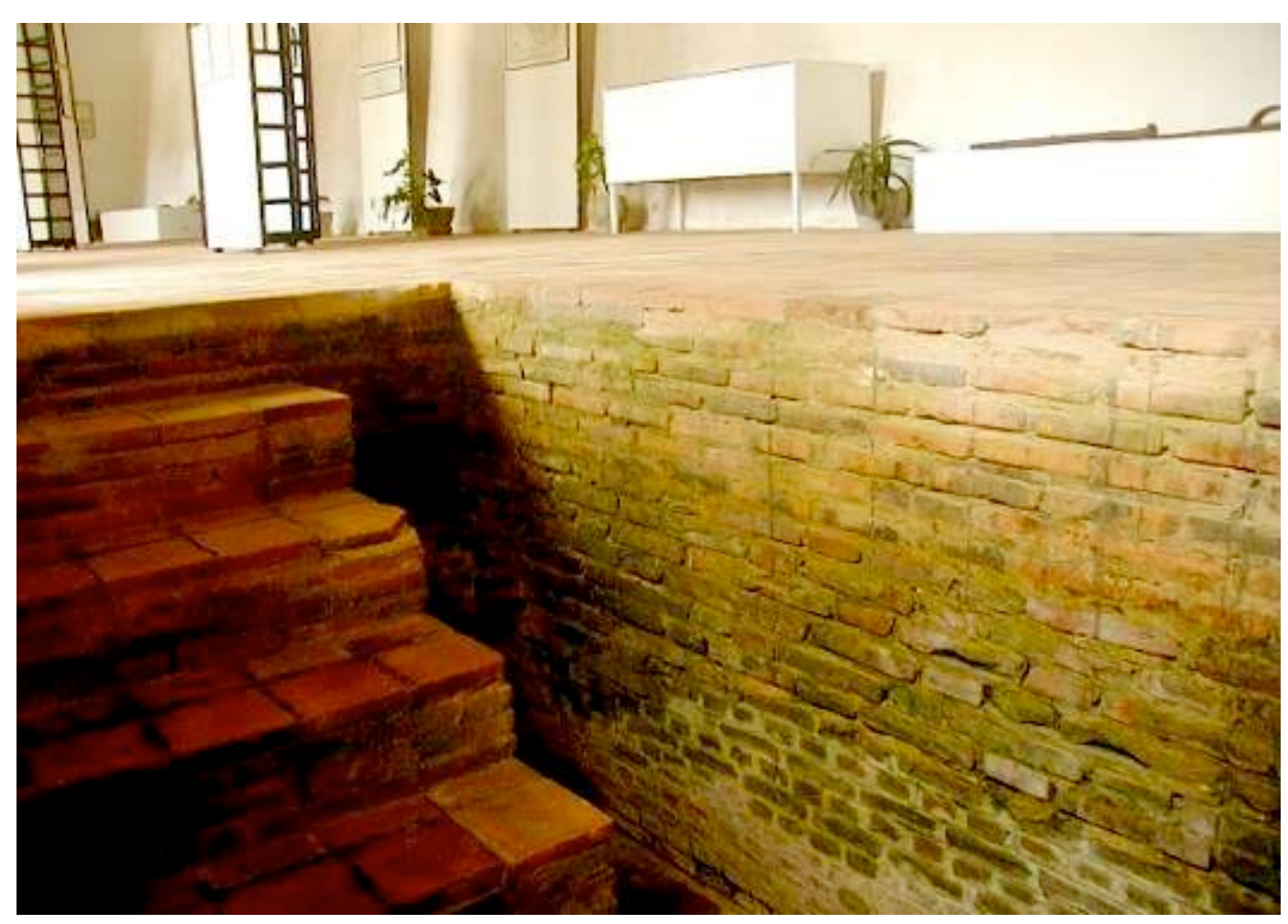

Figura 21: Detalhe da escada reconstruída, vendo-se ao fundo a antiga parede da casa de pólvora, em parte reconstituída. . Foto: Doris Walmsley, 2002. 


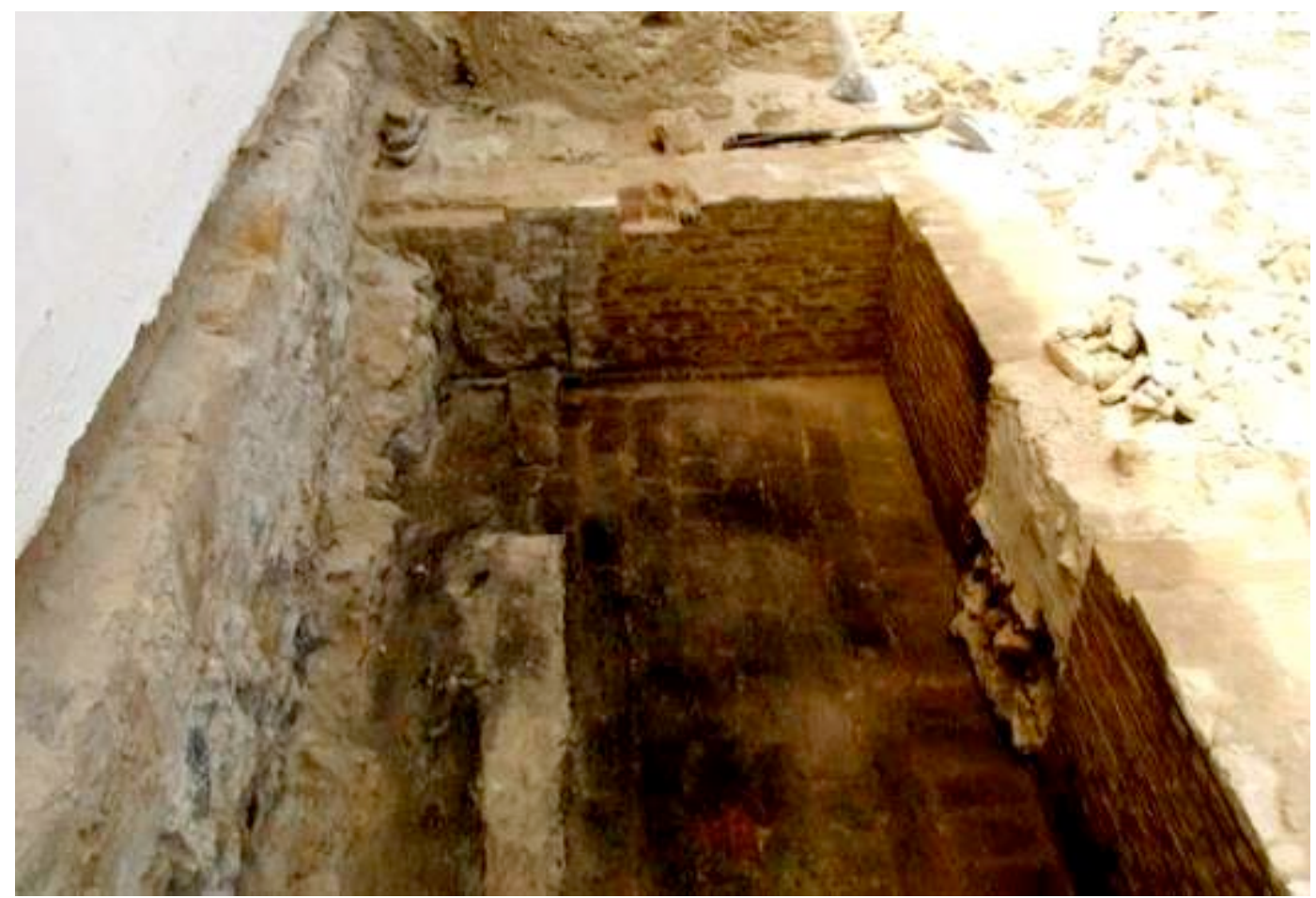

Figura 22: Interior da casa de pólvora depois de escavada. Observe-se a tijoleira (piso original) em tijolos vermelhos, contrastando com as paredes construídas, parte também em tijolos vermelhos e parte em tijolos amarelos holandeses. . Foto: Doris Walmsley, 2003.

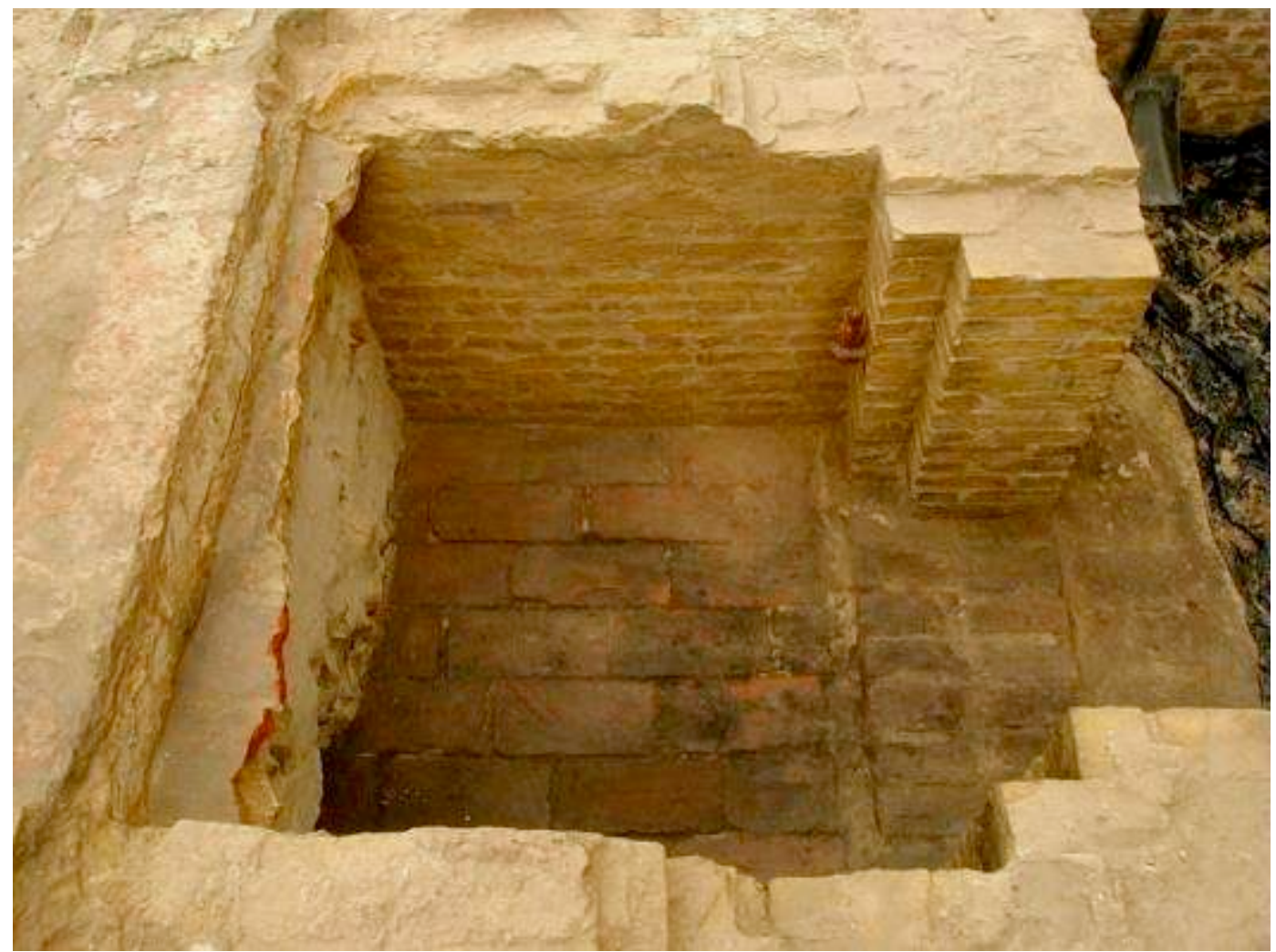

Figura 23: Vista da área de acesso à casa de pólvora, depois da escavação. . Foto: Doris Walmsley, 2003. 


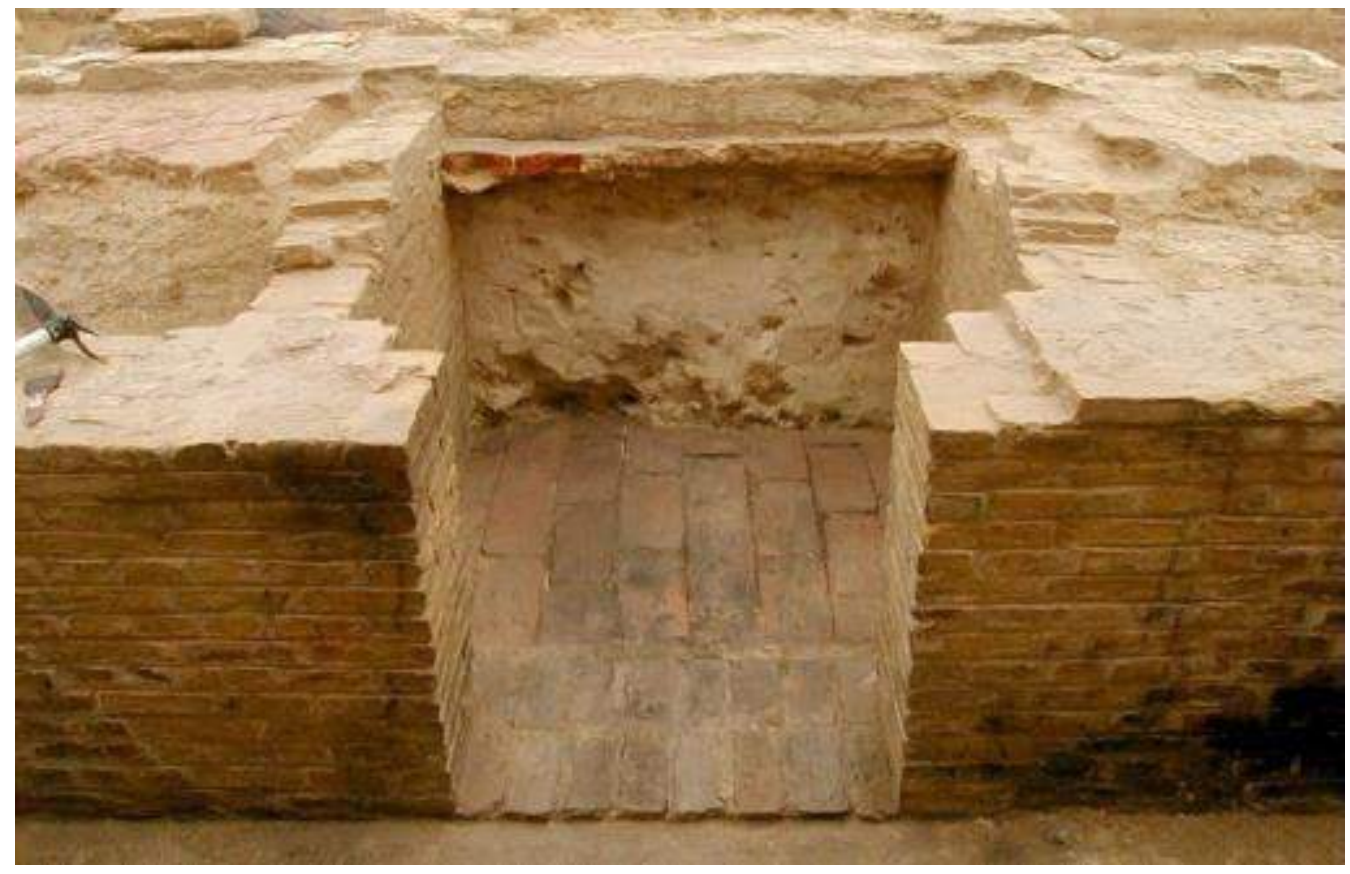

Figura 24: Outro detalhe da área de acesso à casa de pólvora. . Foto: Doris Walmsley, 2003.

Durante o desenrolar da pesquisa, as ruínas da casa de pólvora permaneceram abertas à visitação tanto de estudiosos quanto do grande público visitante, sempre muito interessado em conhecer os achados (Figura 25).

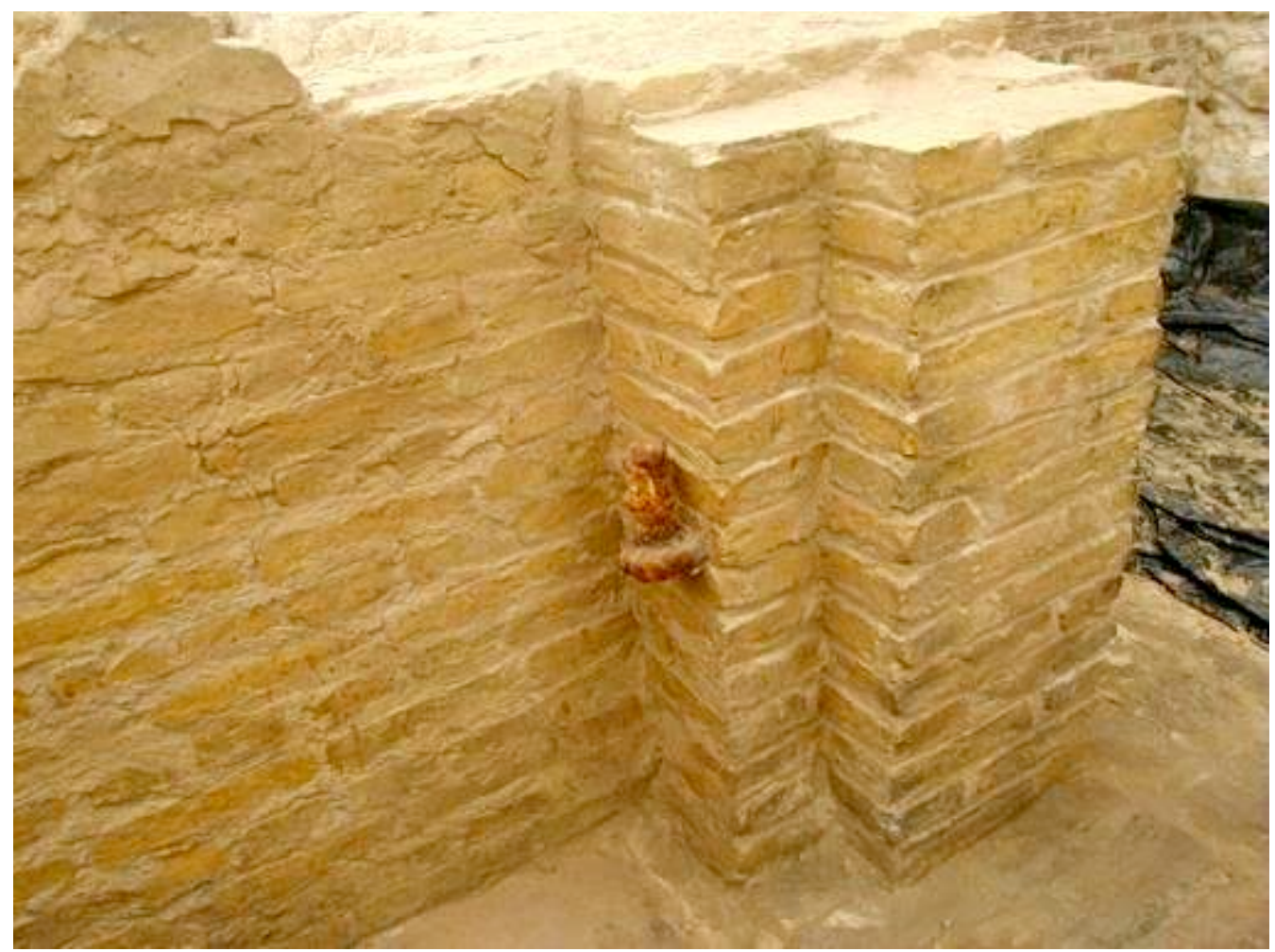

Figura 25: Observe-se parte da dobradiça que suportava a porta interna da casa de pólvora, ainda fixada na parede. . Foto: Doris Walmsley, 2003. 
Com vistas a sua preservação, ao fim da escavação arqueológica, a área da casa de pólvora foi coberta por um tapume de Madeirit, apoiado em suportes de madeira e revestido com lona plástica, visando protegê-la de eventuais curiosos que pudessem por em risco as frágeis estruturas (Figura 26). Por outro lado, visando a segurança do público visitante, a área foi cercada com tela plástica até a altura de 1,5 m (Figuras 27 e 28).

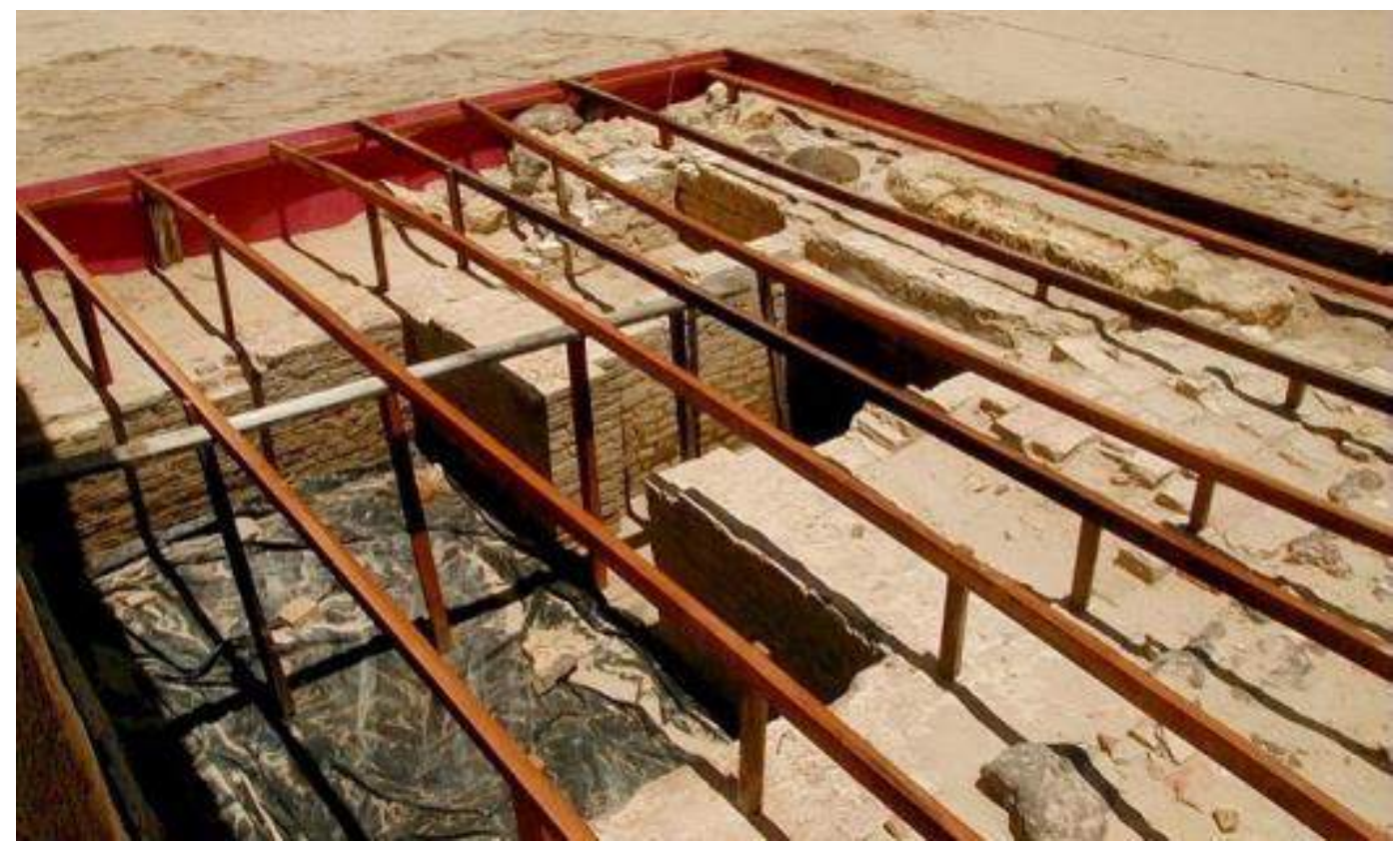

Figura 26: Engradado para suportar a cobertura em madeira, de proteção. Foto: Doris Walmsley, 2003.

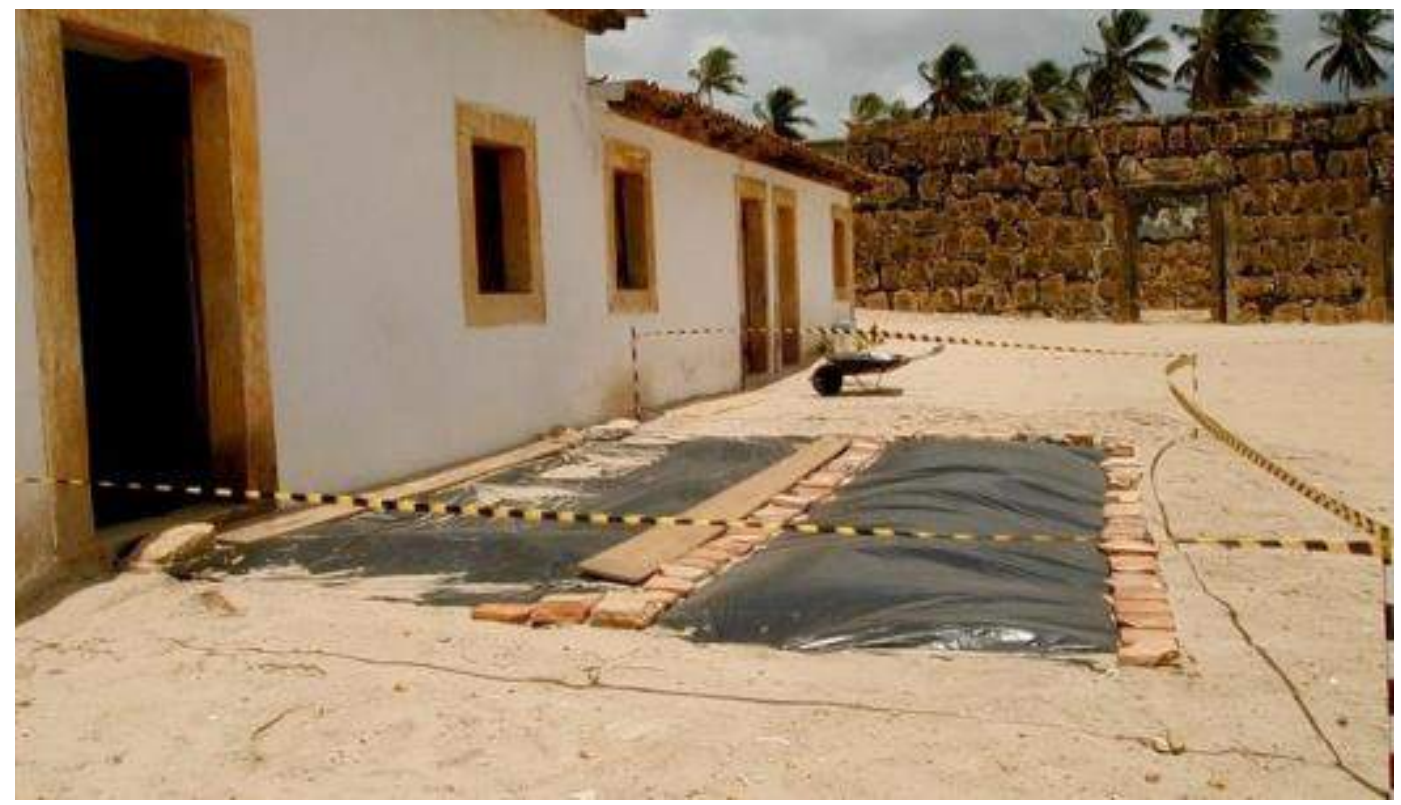

Figura 27: Coberta em lona plástica para evitar o acúmulo das águas de chuva. Foto: Doris Walmsley, 2003. 


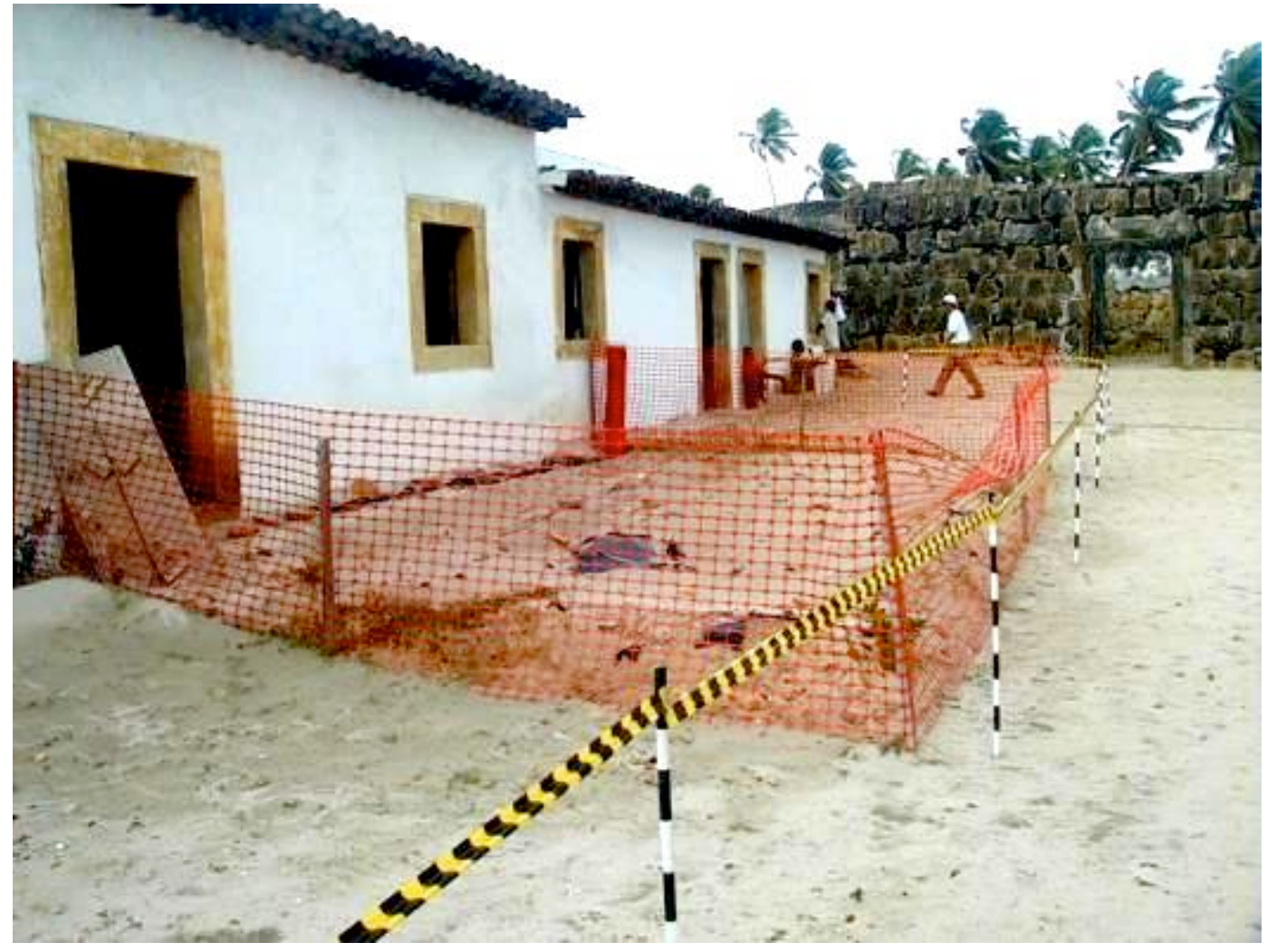

Figura 28: Tele de proteção para evitar o pisoteio. Foto: Doris Walmsley, 2003.

Neste contexto, buscou-se assim preservar aquela estrutura até que seja submetida ao necessário trabalho de consolidação / proteção. Esta estrutura deve ser consolidada, bem como estudado o modo de restituir-se, ou não, sua dimensão integral, de maneira a torná-la ponto de visitação pública.

\section{Escavação nos terraplenos: A antiga porta holandesa}

Em se considerando a iconografia publicada por Gaspar Barléu, em seu livro História dos feitos recentemente praticados nos oito anos no Brasil, que ilustra a llha de Itamaracá e ainda a planta encontrada no Arquivo do Reino, em Haia, o portão de acesso ao Forte Orange estaria voltado para o Canal de Santa Cruz (voltado aproximadamente para Sul). A versão luso-brasileira do forte, entretanto apresenta o portão voltado para a então Vila Conceição (atual Vila Velha), ou seja, voltado aproximadamente para Oeste (Figura 29). 


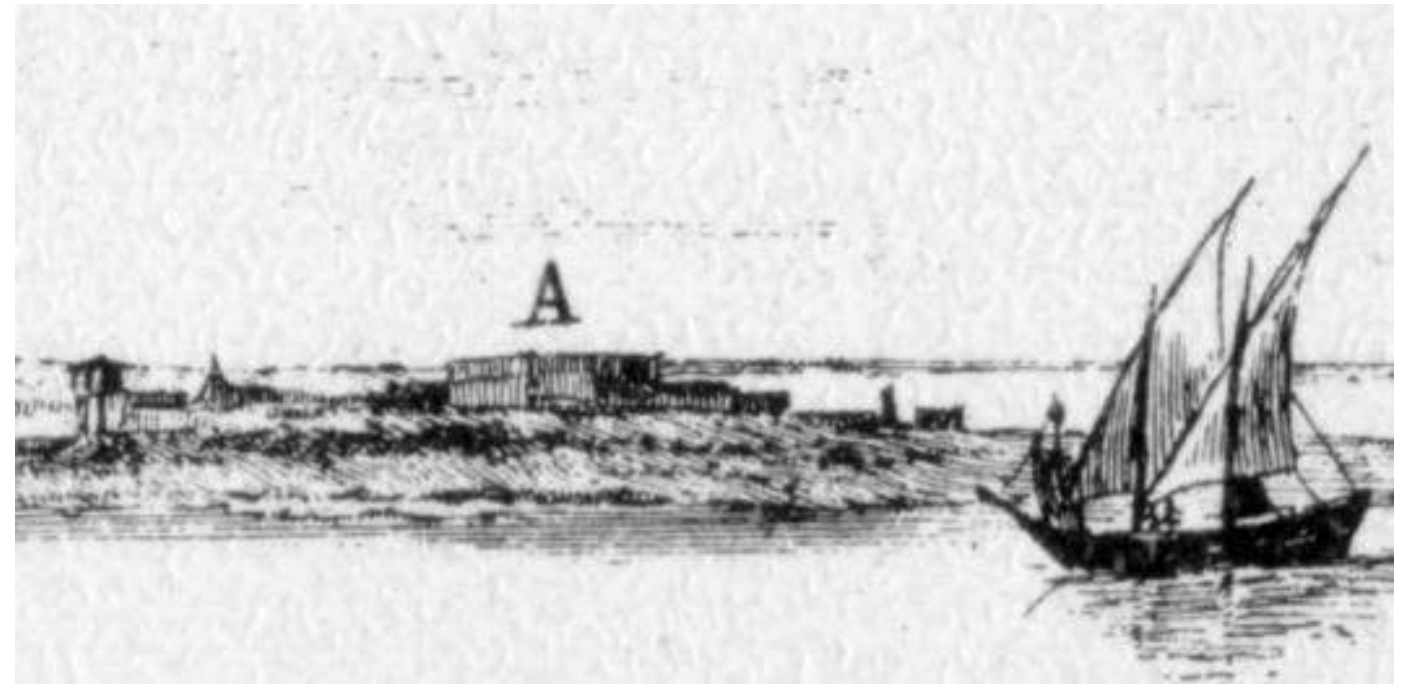

Figura 29: Ilha de Itamaracá, na altura do canal sul, vista do continente, com a Cidadela Schkoppe (Vila da Conceição) e o Forte Orange. (Detalhe da planta do Forte Orange). Desenho de Franz Post 1645, inserto na obra História dos Feitos Recentemente Praticados Durante Oito Anos no Brasil, de Gaspar Barléu. Ed. Fund. Cult. Cidade do Recife. Recife 1980. Rep. Fac-similar das gravuras que ilustram a 1a edição de 1647.

Durante o período de ocupação holandesa teriam existido pelo menos três diferentes versões do forte. A primeira, apenas uma pequena estrutura de defesa construída, às pressas, durante o primeiro momento de ocupação da llha. Ao longo do tempo teriam possivelmente havido ampliações ou novas construções. Para a segunda versão já teriam contado com o concurso efetivo de pessoas qualificadas para a construção de obras de defesa.

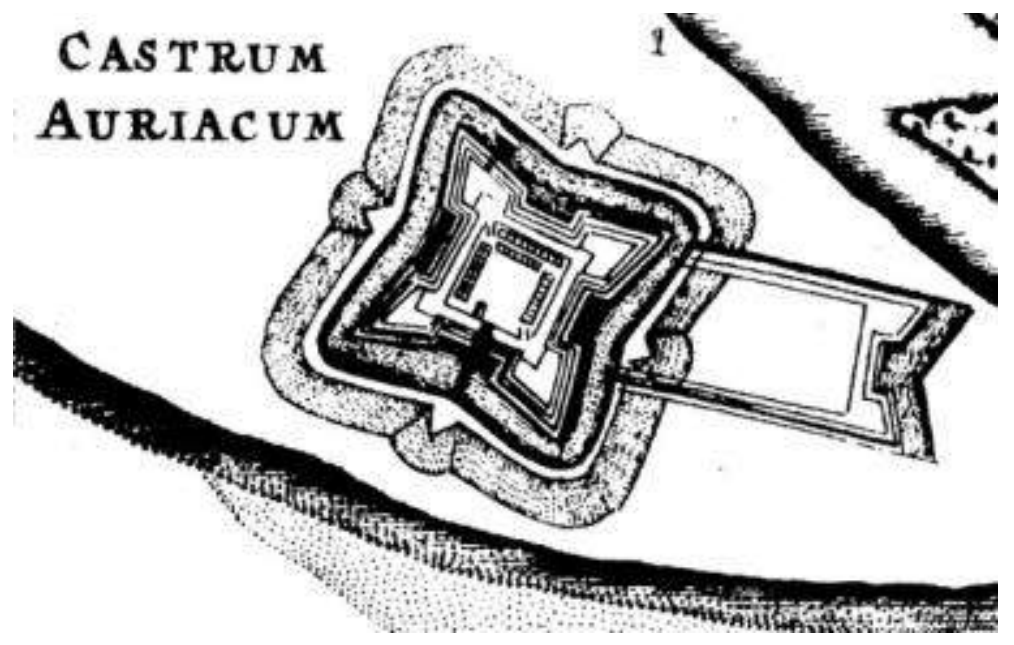

Figura 30: Detalhe do Mapa da Ilha de Itamaracá. Estão representados a Cidadela Schkoppe (Vila da Conceição) e o Forte Orange. Autor desconhecido. Inserto na obra História dos Feitos Recentemente Praticados Durante Oito Anos no Brasil, de Gaspar Barléu. Ed. Fund. Cult. Cidade do Recife. Recife 1980. Rep. Fac-similar das gravuras que ilustram a 1a edição de 1647. 
Mesmo assim, o resultado parece não ter atendido à administração, que posteriormente investiria no aprimoramento do forte. É esta terceira versão que é descrita por Laet $^{2}$ como tendo uma bela entrada em alvenaria. Esta descrição coadunava-se com o plano da entrada do forte mostrado pelas duas iconografias mencionadas anteriormente (Figuras 31 e 32$)$.

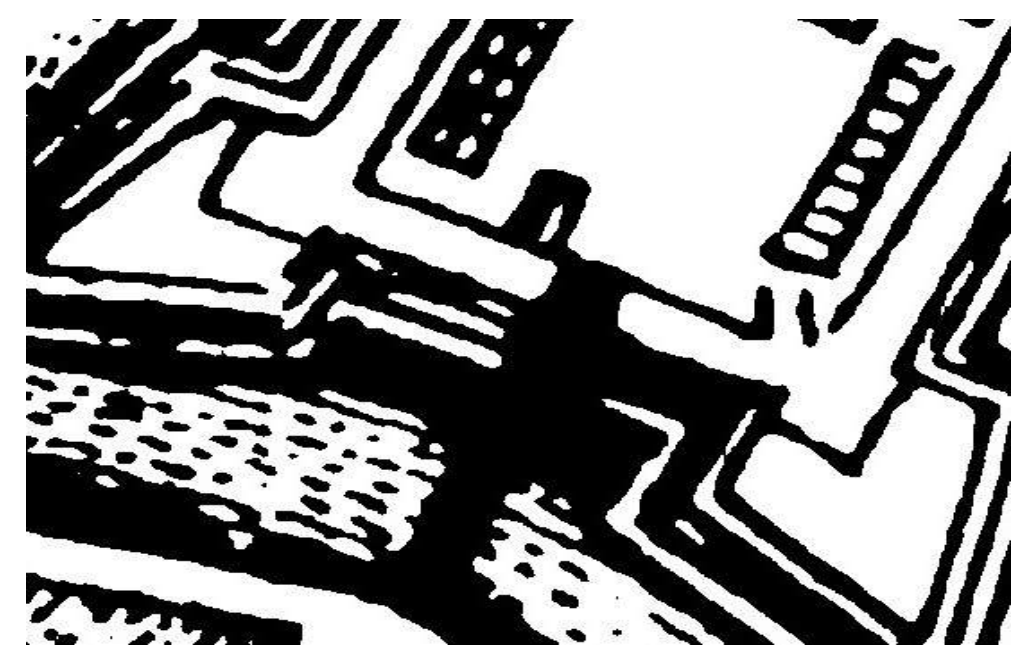

Figura 31: Detalhe da porta na planta inserta em Barléu.

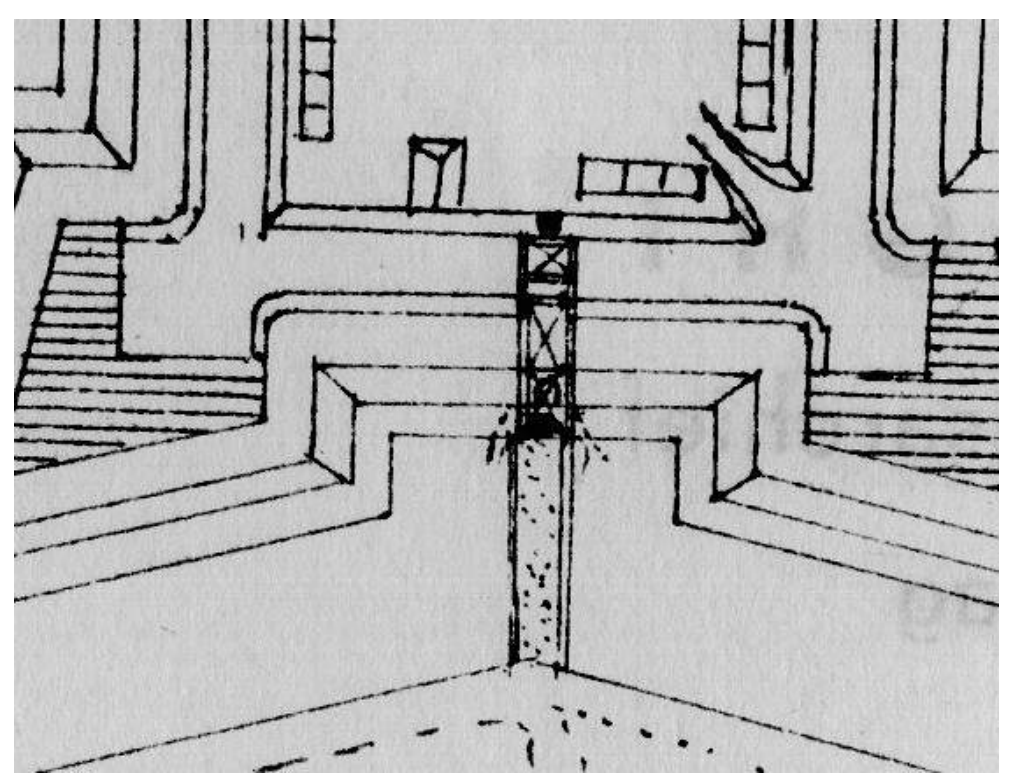

Figura 32: Detalhe da porta na planta encontrada no Arquivo do Reino, em Haia (autor não identificado até o momento).

2 Joannes de Laet, laerlyck Verhael (periode 1624-1636) uitgegeven 1644, 13 boeken / L'Honoré-Naber en Warnsinck 19311937,4 vols. 
A estratégia utilizada para buscar-se a antiga porta de acesso considerou diferentes hipóteses:

\section{Hipótese 1}

O forte holandês em seu último período teria suas muralhas construídas em pedra. Atendendo a esta hipótese, as evidências da antiga porta holandesa deveriam ser buscadas em três pontos:

- Junto à atual Cortina 3-4;

- No interior da Dependência 12, junto à parede 12-4; e

- Na área do terrapleno 3-4.

De fato, tanto na face externa da muralha, no trecho da cortina 3-4, quanto no interior da Dependência 12, parede D12-4, podem ser observadas marcas que sinalizam no sentido de uma construção não homogênea (Figura 33 e 34).

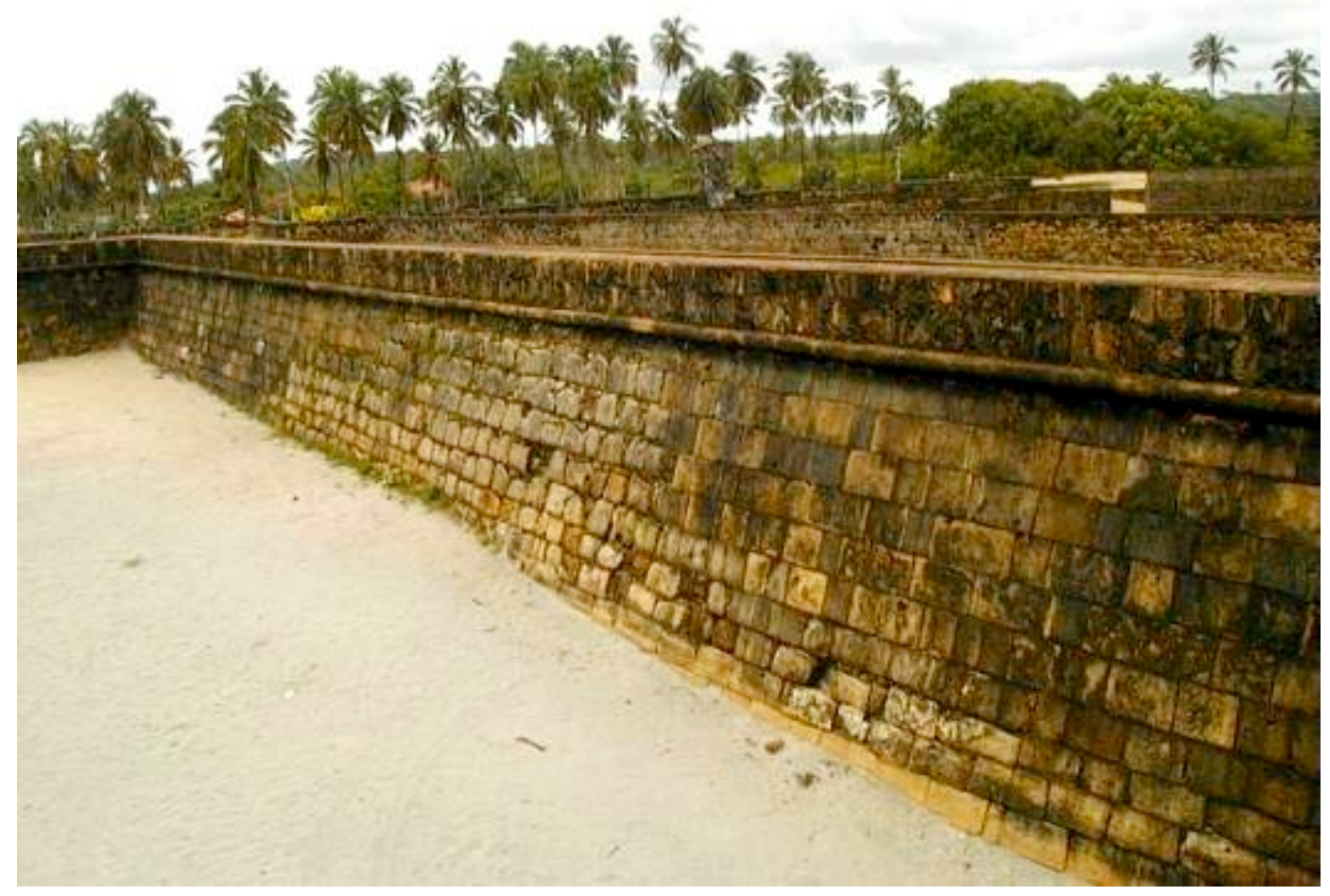

Figura 33: Foto da cortina 3-4 vista pela muralha. Foto: Doris Walmsley, 2002. 


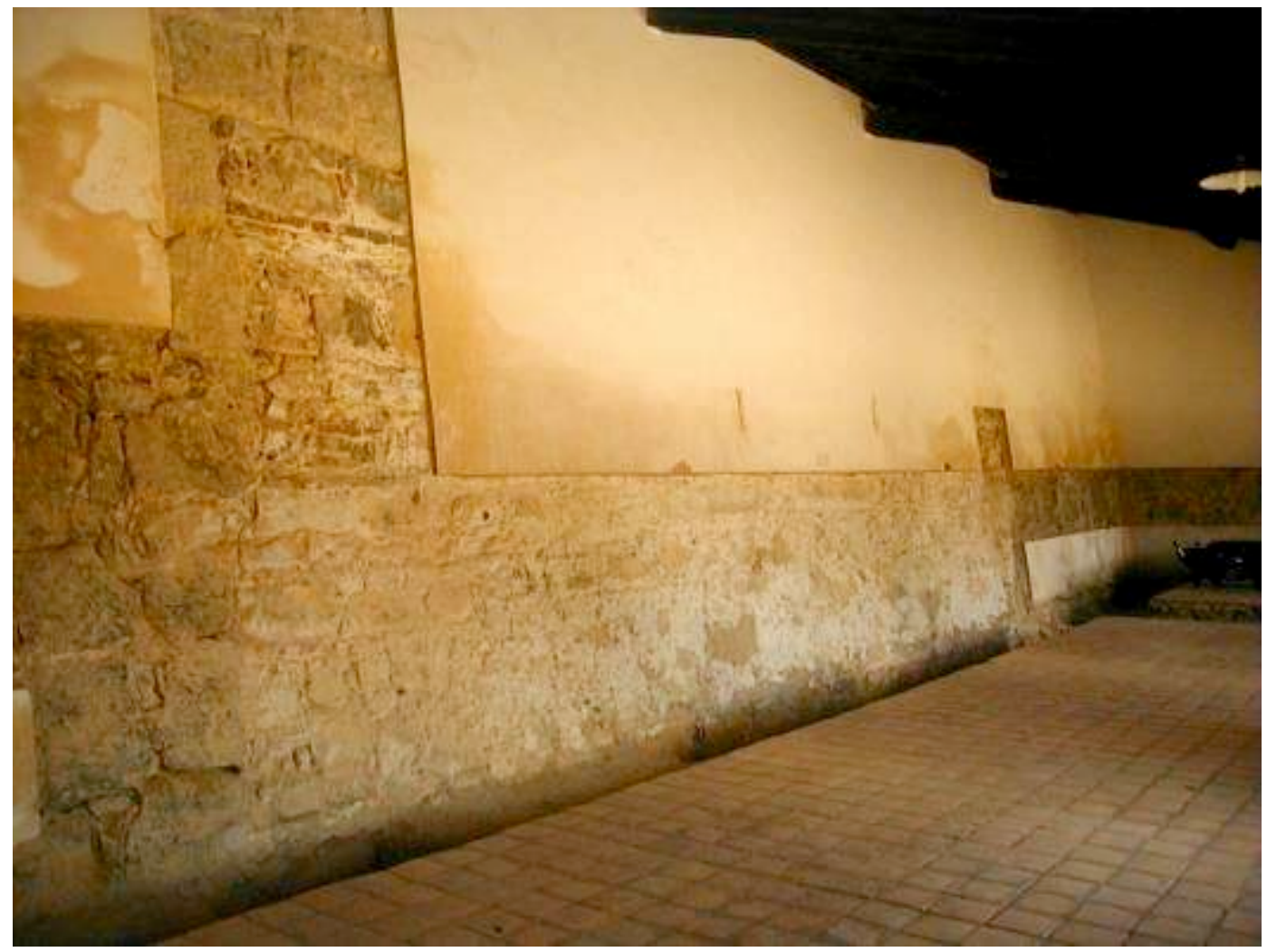

Figura 34: Contra-muralha vista do interior da dependência 12. Tanto as pedras utilizadas como a argamassa que as rejunta oferecem um claro indicador de mais de uma etapa de construção. Foto: Doris Walmsley, 2002.

Seriam reparos posteriores tanto da muralha quanto da contra-muralha, ou entaipamentos de aberturas que haviam caído em desuso? Os estudos realizados puderam relacionar as alterações na contra-muralha à construção e demolição da "casa do Cabo, de sobrado baixo".

\section{Hipótese 2}

O forte holandês em todo o período teria suas muralhas construídas em terra e madeira. Considerando-se esta hipótese, ter-se-ia que a atual muralha (em pedra) seria de construção posterior à ocupação holandesa. Neste caso, a área da antiga porta poderia se encontrar circunscrita ao terrapleno atual.

A análise comparativa da planta holandesa do século XVII, com o traçado do forte no século XVIII, revela a impossibilidade de um "encamisamento", como foi sugerido por alguns autores. Sobretudo as proporções entre os baluartes e as cortinas, independentemente das escalas de uma e de outra planta, mostra a incompatibilidade e uma continuidade com base no revestimento de pedras sobre as paredes do anterior. Mas a sucessão entre os fortes não deveria por isto ser descartada (Figura 35). 


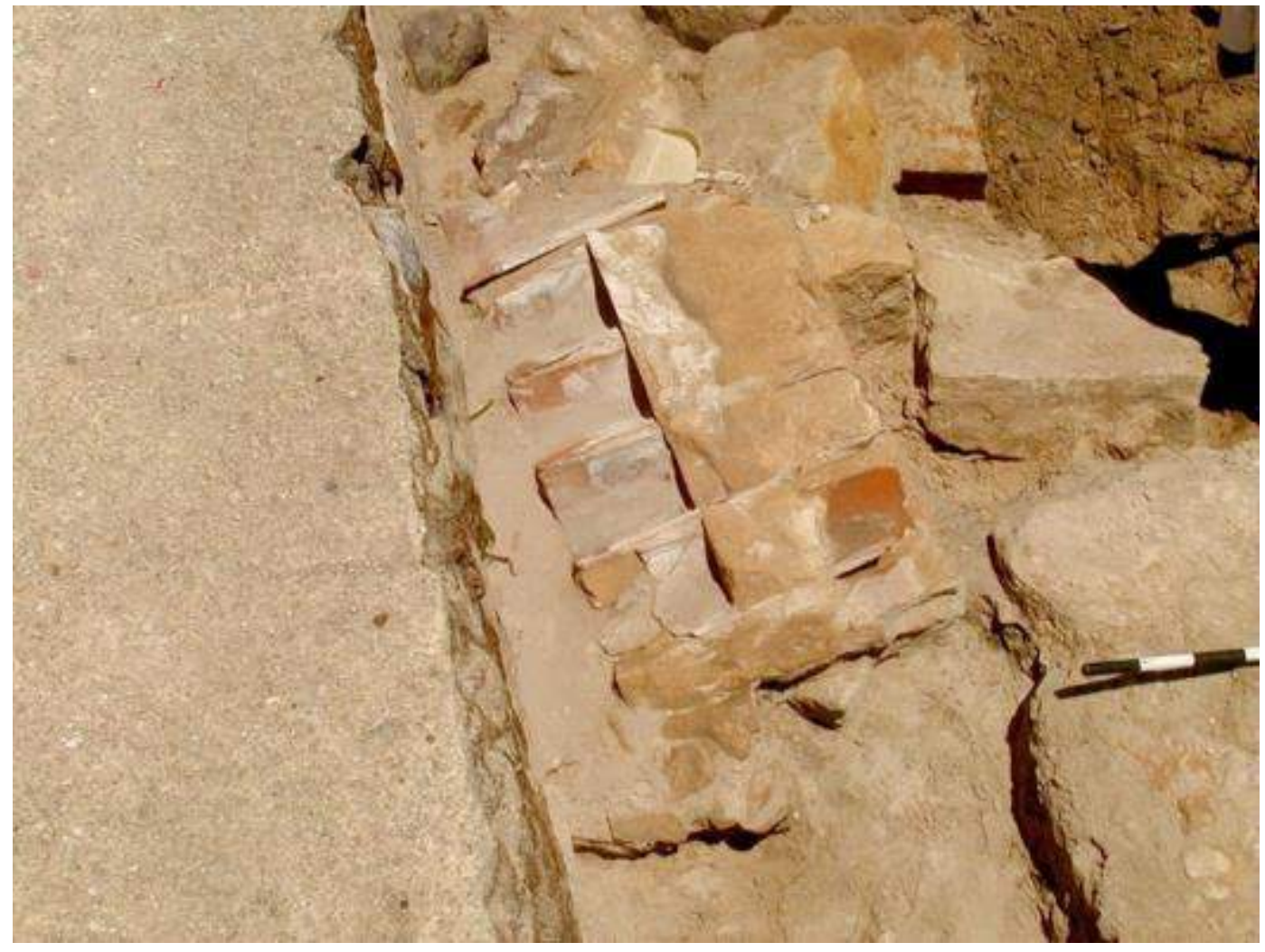

Figura 35: Blocos de alvenaria de tijolos e pedras, grandes porções de beiral encontrados durante a escavação no aterro do terrapleno 3-4. Foto: Doris Walmsley, 2003.

A escavação do terrapleno 3-4 revelou inicialmente a presença de grandes blocos de antigas construções destruídas, deixados no interior do "reparo" do terrapleno (Figura 36 e 37). Os blocos de alvenaria de tijolos rejuntados com argamassa de cal, associados a um conjunto de telhas formando um beiral, evidenciam a possibilidade de se estar trabalhando sobre os destroços da "casa do comandante do forte", que existira sobre o terrapleno, conforme consta em planta do século XVIII. Tratava-se, entretanto de material semelhante àquele que compunha o telhado e as paredes de alvenaria de tijolos que limitavam a atual dependência 12 . 


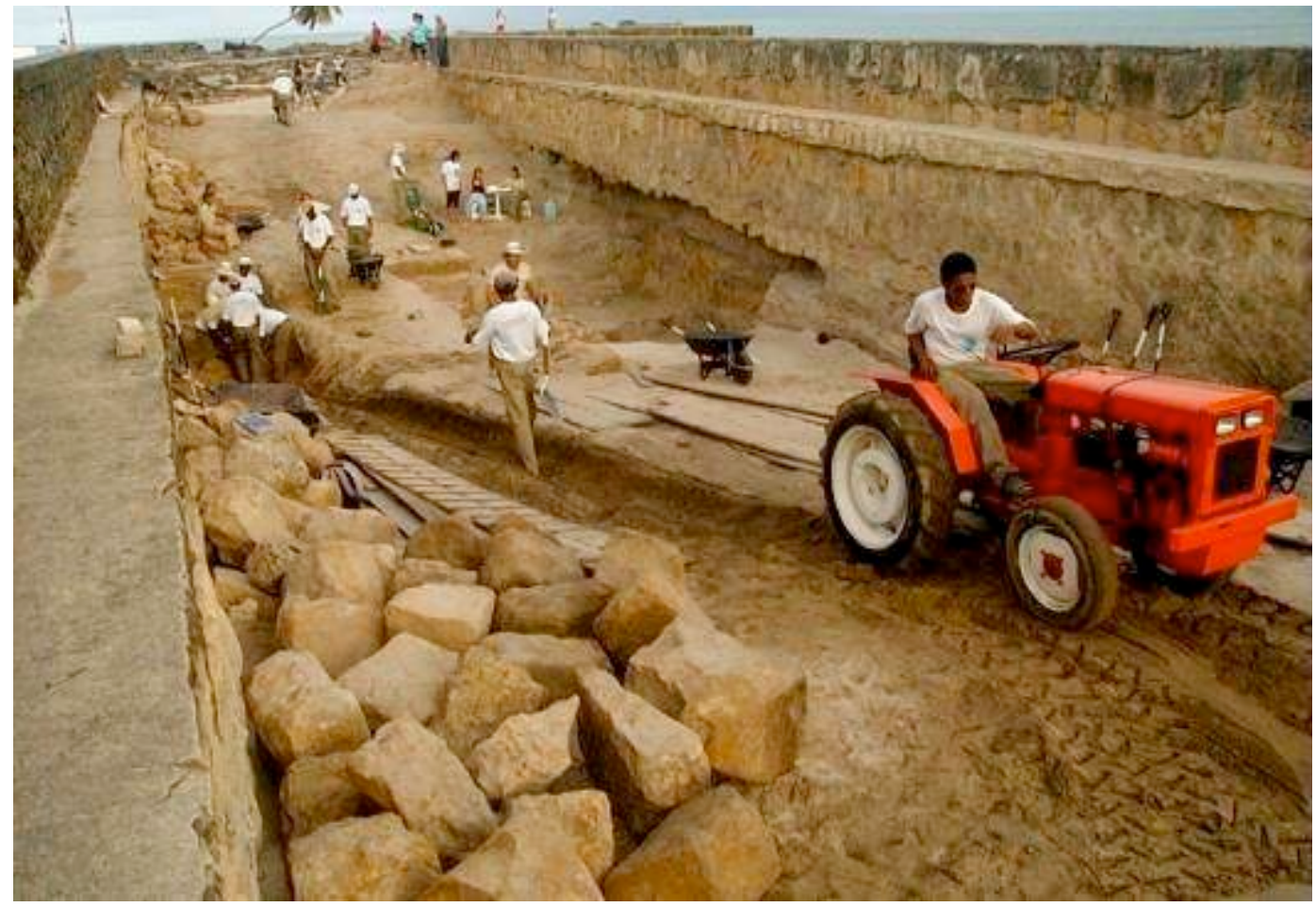

Figura 36: A remoção de muitos dos grandes blocos de calcário se fez com o auxílio de máquinas. Foto: Doris Walmsley, 2003.

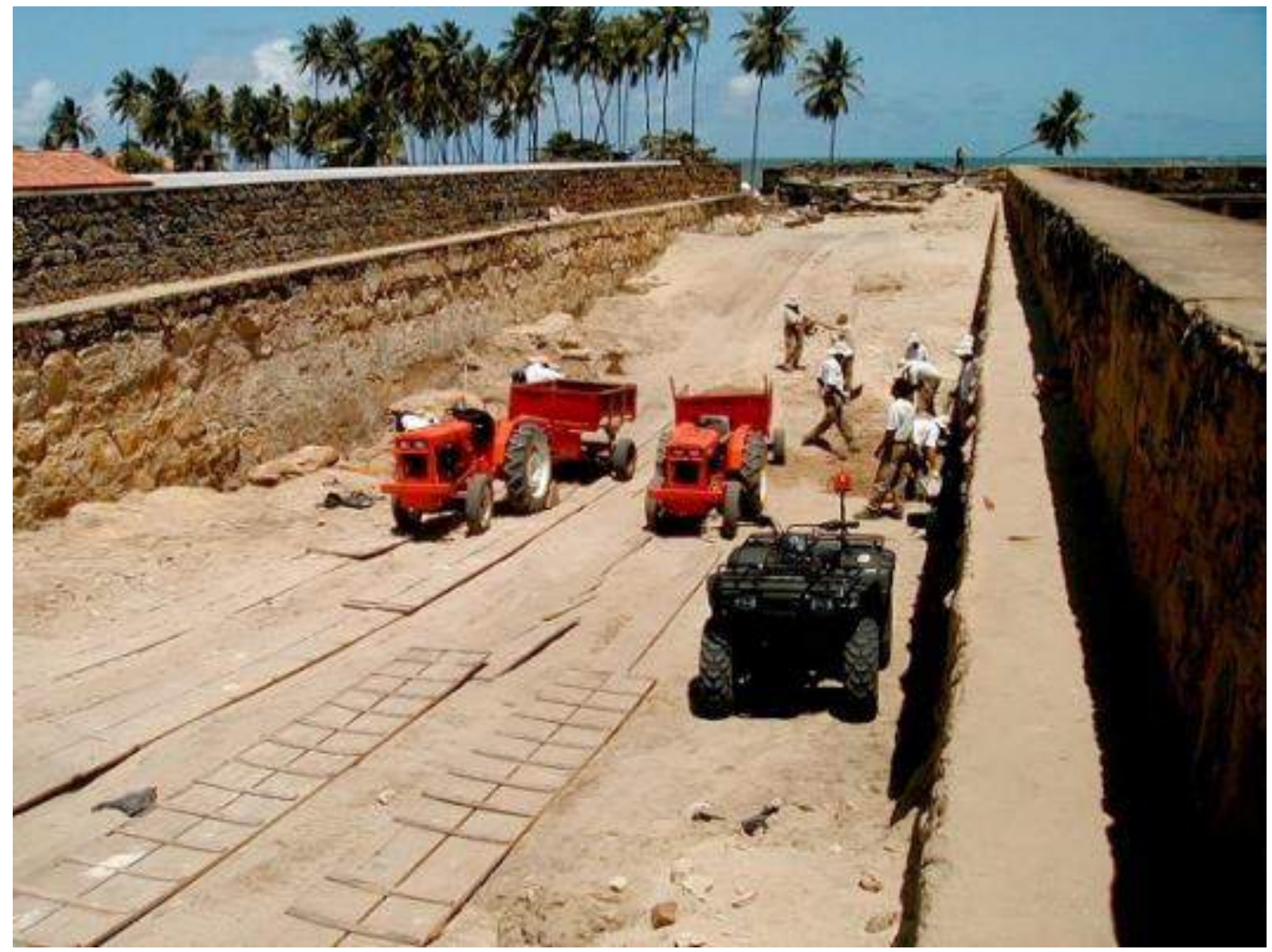

Figura 37: Aspecto da escavação com remoção mecânica do aterro do terrapleno 3-4. Foto: Doris Walmsley, 2003. 
Por outro lado, os grandes blocos de calcário presente nas camadas mais elevadas estavam relacionados à "casa de sobrado baixo", como também é referida em planta a casa do comando. Dentre os blocos de pedra trabalhada, um deles está relacionado à ombreira da porta holandesa. Pode-se observar ainda a presença de duas pedras trabalhadas que se completam constituindo um arco, possivelmente também relacionado à porta holandesa. Buscava-se ainda, no interior deste terrapleno, vestígios da antiga porta holandesa, possivelmente protegida por uma abóbada de alvenaria

Embora em termos de profundidade a escavação arqueológica da campanha de 2002 tenha atingido o nível correspondente ao piso da dependência 12, a natureza do material de preenchimento do terrapleno (areia) impediu a acesso em profundidade, a uma área necessária e suficiente para o estudo mais completo. Apesar de ter-se escavado a partir de um corte amplo na superfície, o escalonamento da escavação, exigido pelo gradiente de repouso da areia, apenas permitiu atingir aquela profundidade (cerca de 5,30 m) em uma pequena área. Assim fez-se necessário prosseguir com os estudos naquele terrapleno por ocasião da campanha de 2003.

Naquela etapa optou-se por escavar por completo o terrapleno (Figuras 39), removendo em toda a amplitude as sucessivas camadas. $O$ uso dessa estratégia permitiu a localização da antiga porta de acesso ao forte. Um portal em cantaria, ladeado por grossas paredes de tijolos (Figura 38). Ali foi localizada a entrada do forte, com seu portão voltado para o Canal de Santa Cruz, onde quase sempre haviam navios fundeados. Uma entrada não muito ampla, entretanto de estrutura "monumental" (Figuras 40). Parte do conjunto havia sido destruído quando da construção, no século XVIII, da "casa do Cabo" referida em planta setecentista.

Ainda na área do terrapleno foram resgatadas estruturas em terra, com vestígios de madeira que remontam ao primitivo forte holandês, retratado na iconografia. Os vestígios de madeira provavelmente decorrem de uma cerca que coroava a muralha de terra que circundava o forte (Figura 41 e 42).

Todas estas descobertas foram possíveis graças a uma abordagem ampla e, sobretudo sistemática do sítio arqueológico. Uma abordagem que se reflete no avultado número de $\mathrm{m}^{3}$ de terra escavada e peneirada, com resultados que em muito ultrapassam as expectativas mais otimistas. 


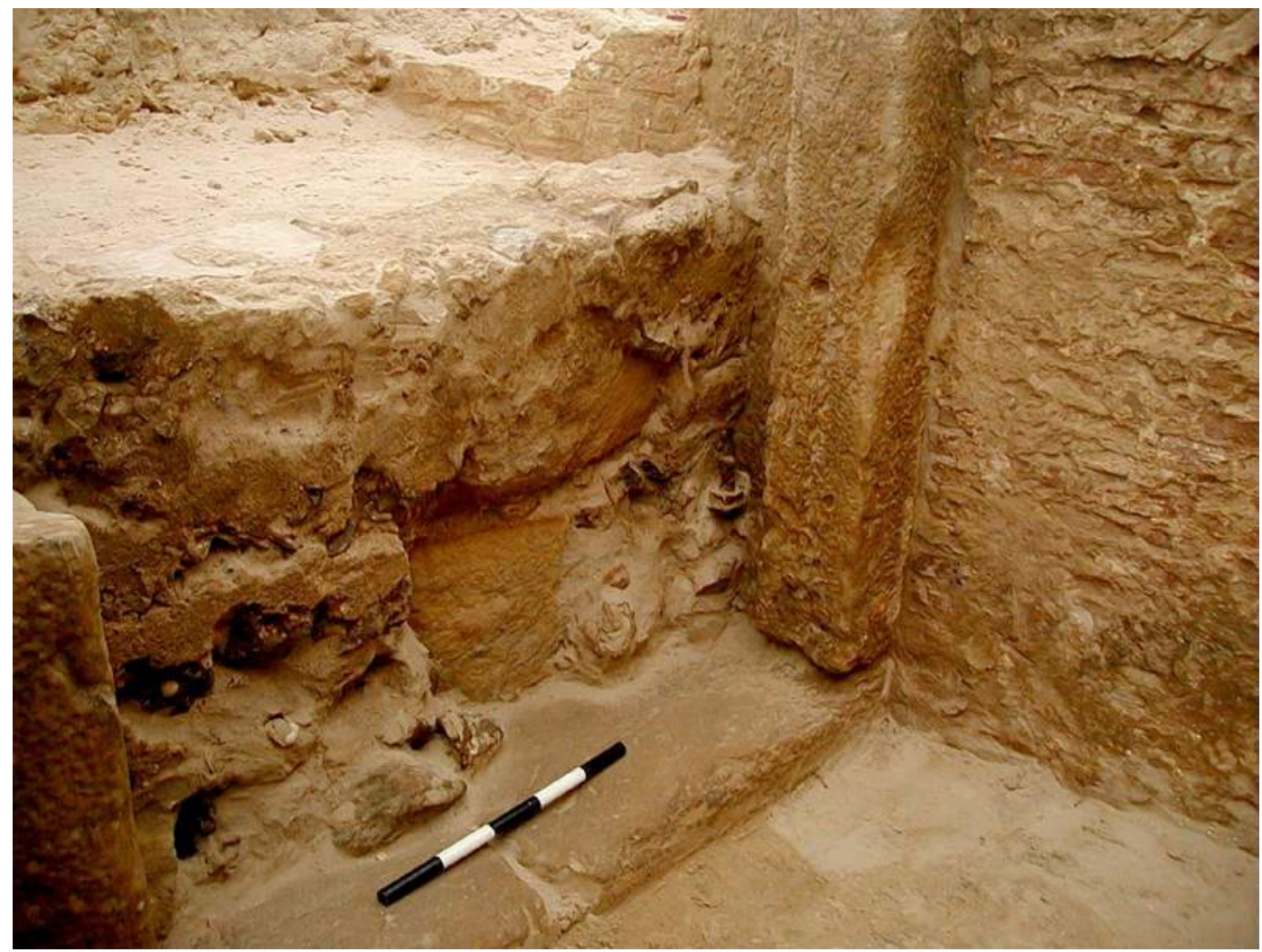

Figura 38: A antiga porta holandesa foi fechada com uma parede de pedras, provavelmente ainda durante a construção do forte luso-brasileiro. Foto: Doris Walmsley, 2003.

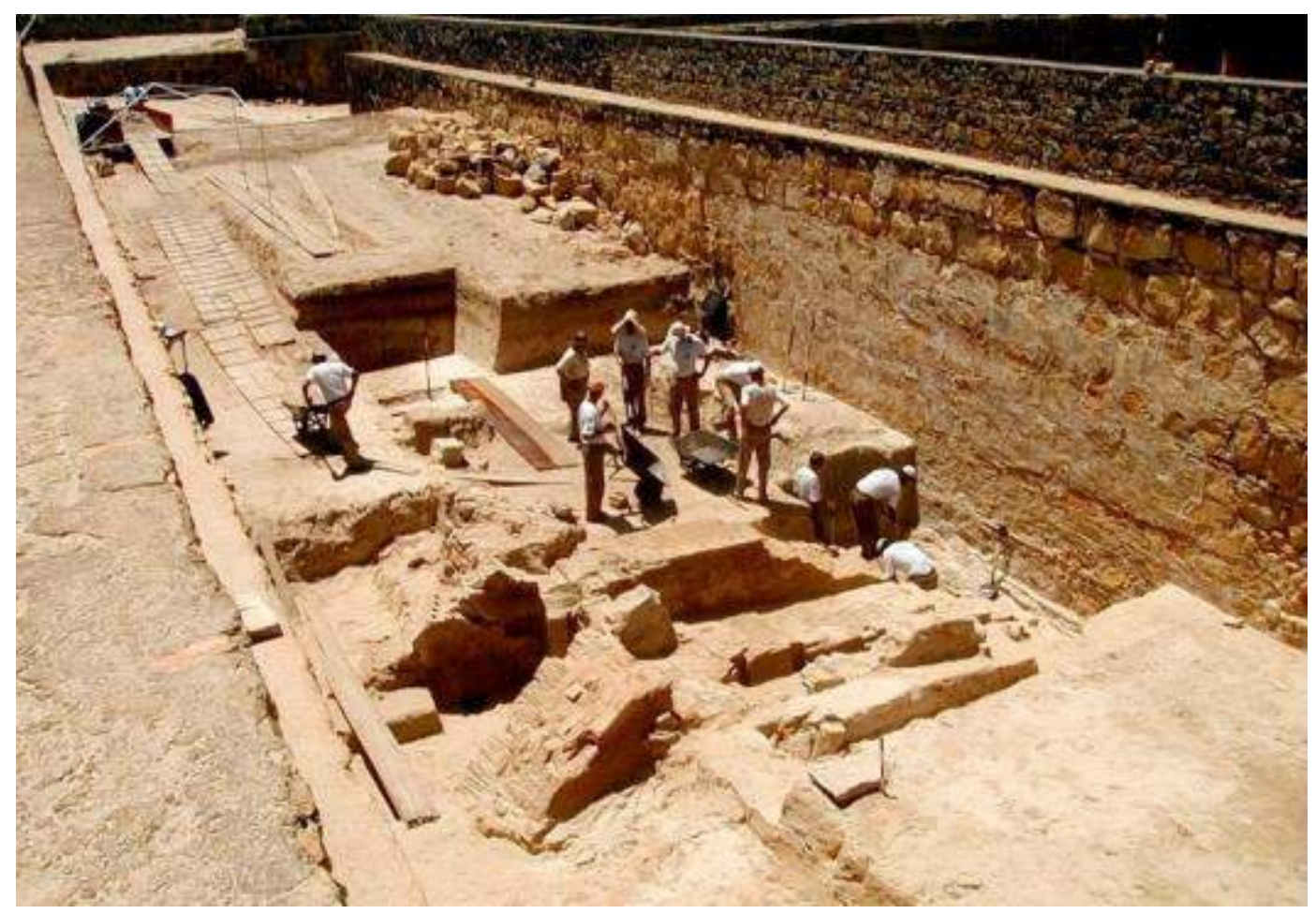

Figura 39: Conjunto das estruturas relacionadas à antiga porta do Forte Orange. Foto: Doris Walmsley, 2003. 


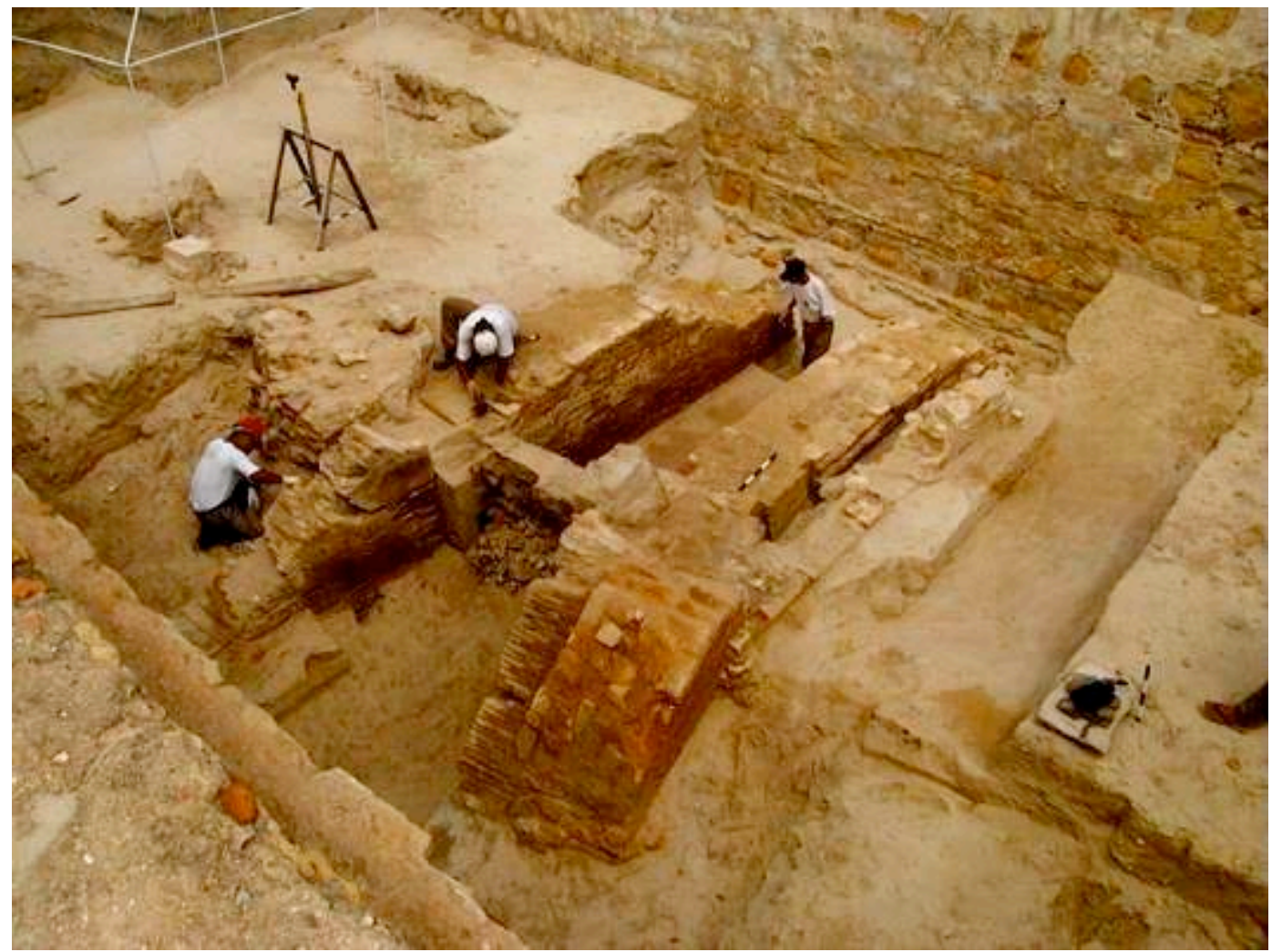

Figura 40: Vista do conjunto da estrutura da antiga porta. Foto: Doris Walmsley, 2003.

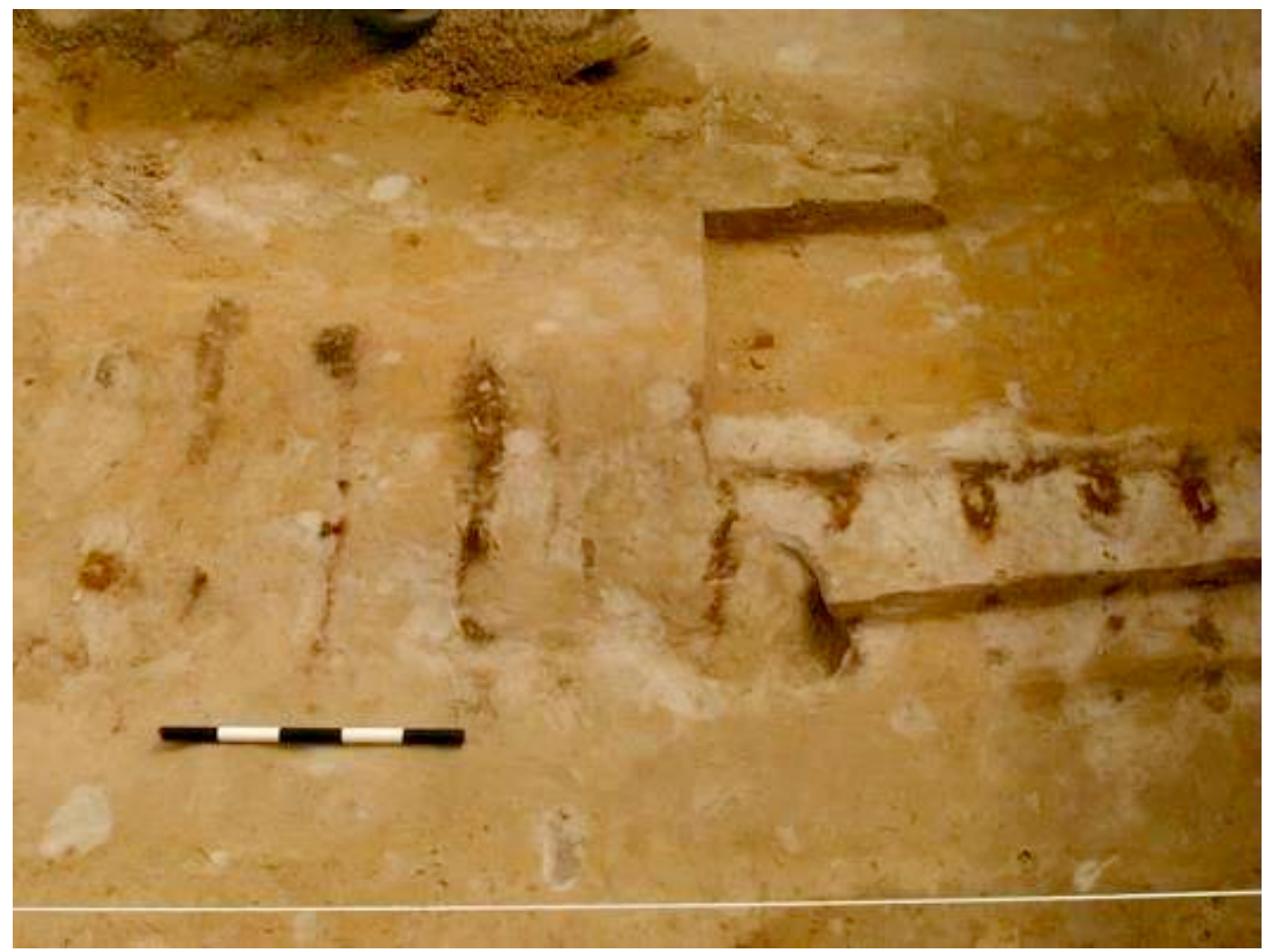

Figura 41: Vestígios de madeira que remontam ao primitivo forte holandês. Foto: Doris Walmsley, 2003. 


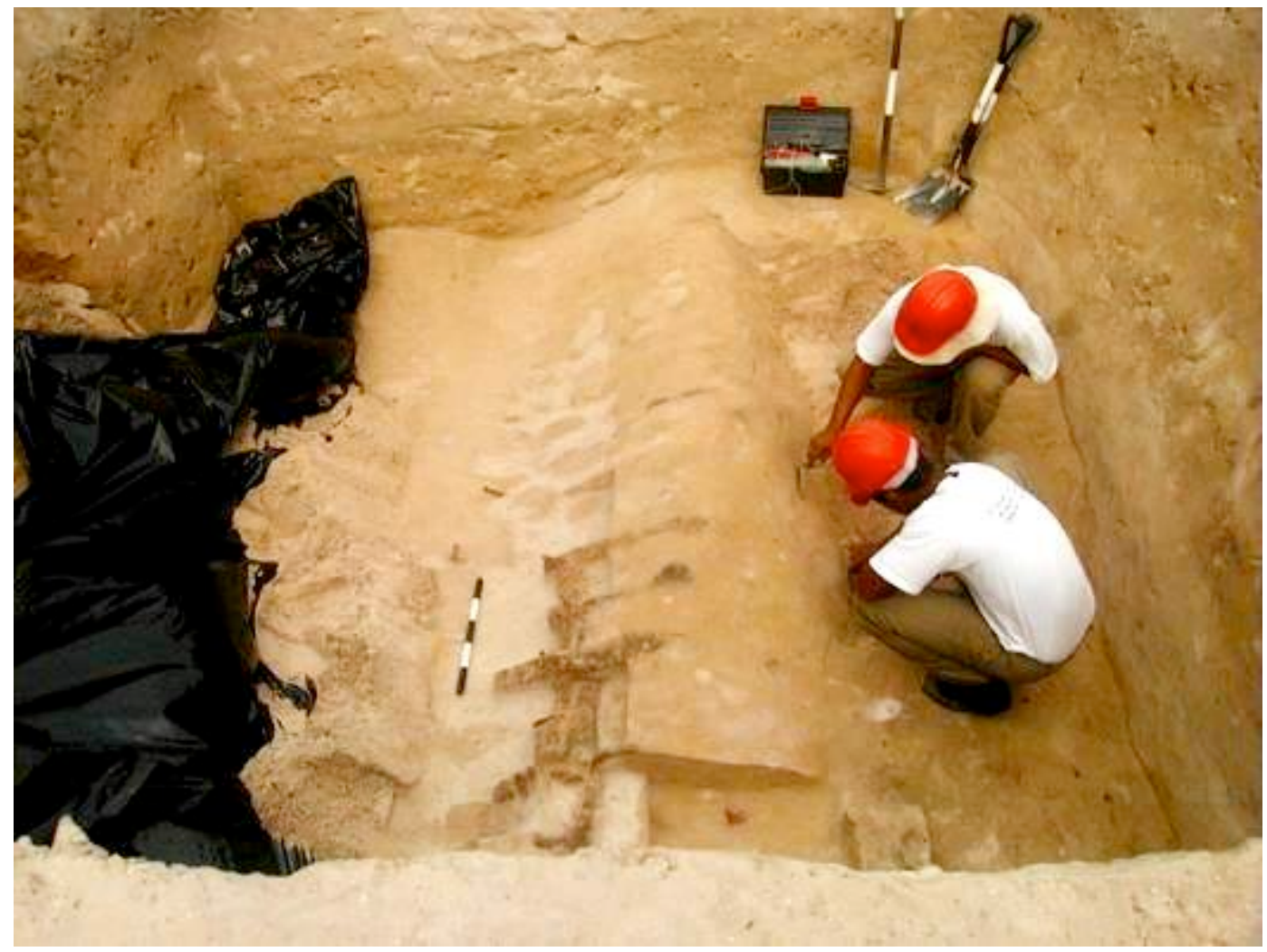

Figura 42: Remanescente de antiga muralha de terra, encimada por estacas de madeira, presas entre si por cravos de ferro, com cerca de $20 \mathrm{~cm}$ de comprimento. Foto: Doris Walmsley, 2003.

\section{Considerações finais}

A escavação arqueológica da praça de armas, assim como dos terraplenos, trouxe novos elementos relacionados às antigas estruturas. Esclareceu quanto à individualidade de cada um dos fortes que se sucederam; suas dimensões, estruturas internas, distribuição espacial e material de construção. Assim, foi possível se ter uma visão do conjunto do interior do forte no último período de ocupação holandesa, com seus quartéis distribuídos no interior da praça. Inclui-se nessa visão, reconstituída a partir da pesquisa arqueológica, detalhes da concepção holandesa do interior daqueles alojamentos de tropas.

Com a descoberta dos antigos quartéis é possível se avaliar as dimensões do forte original. Por outro lado, foi possível ainda identificar que a atual área da praça de armas abrange uma área que excede aquela outrora ocupada pela antiga praça de armas holandesa.

Neste contexto, teve-se a oportunidade de oferecer aos planejadores da restauração do forte, elementos concretos para apresentar ao público visitante uma visão do forte original. Assim é que, a restauração empreendida pelo Iphan, na Fortaleza de Santa Cruz, 
preservando a unidade daquele forte setecentista, deixou à mostra parte dos remanescentes da construção holandesa. Sob o terrapleno do forte em pedras, ficou aberto à visitação pública os testemunhos da portada do Forte Orange.

É importante observar que o resultado obtido na escavação do Forte Orange não se restringe àquele forte, mas traz novas perspectivas para o conhecimento acerca das estruturas de defesa holandesas no Brasil. Ressalte-se ainda que do ponto de vista do interesse, tanto científico quanto da restauração, e da musealização, as peças encontradas oferecem um forte potencial para exposição (Figura 43).

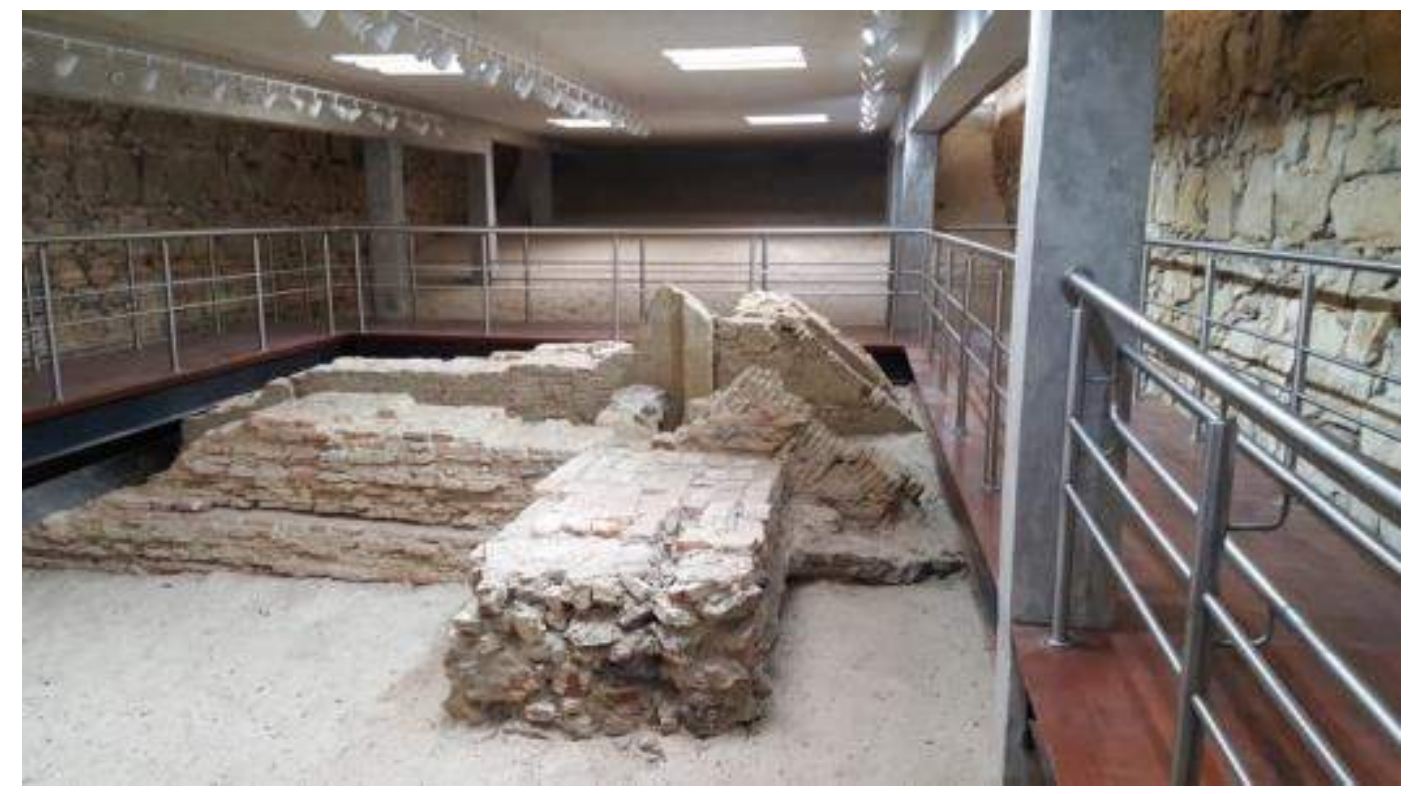

Figura 43: Testemunho arqueológico da antiga porta do Forte Orange. Foto: Rubia Nogueira, 2018.

\section{Referências}

Albuquerque, M. A. G. M. 2010. Arqueologia do Forte Orange II. Revista da Cultura, v. 16, p. 4451

ALBUQUERQUE, M. A. G. M. 2007. As escavações arqueológicas no Forte de Orange. Revista Brasileira de Arqueometria, Restauração e Conservação, v. 01, p. 51-55, Olinda.

AlBuQUeRQUE, M. A. G. M. 2006. As Escavações Arqueológicas no Forte de Orange. In: III Simpósio de Técnicas Avançadas em Conservação de Bens Culturais, Olinda. Anais do III Simpósio de técnicas Avançadas em Conservação de Bens Culturais. Olinda. v. 1.

ALBUQUERQUE, M. A. G. M. 2000. Seminário Internacional para a restauração do Forte Orange. (Apresentação de Trabalho/Seminário). 
BARLÉU, G. 1980. História dos Feitos Recentemente Praticados Durante Oito Anos no Brasil, Ed. Fund. Cult. Cidade do Recife. Recife Rep. Fac-similar das gravuras que ilustram a 1a edição de 1647. BARTHEL, S. G. 2007. Arqueologia de uma Fortificação: O Forte Orange e a Fortaleza de Santa Cruz em Itamaracá, Pernambuco. Dissertação (Mestrado em Arqueologia) - Universidade Federal de Pernambuco.

LAET, J.V. (periode 1624-1636) uitgegeven 1644, 13 boeken / L'Honoré-Naber en Warnsinck 19311937,4 vols.

Planta anônima encontrada no Arquivo do Reino, em Haia. (autor e data não identificados até o momento)

POST, F. 1645. Ilha de Itamaracá, na altura do canal sul, vista do continente, com a Cidadela Schkoppe e o Forte Orange. Desenho de Franz Post Inserto na obra História dos Feitos Recentemente Praticados Durante Oito Anos no Brasil, de Gaspar Barléu. 1980. Ed. Fund. Cult. Cidade do Recife. Recife. Rep. Fac-similar das gravuras que ilustram a 1a edição de 1647. 